ORNL/CDIAC-143

NDP-082

\title{
CARBON DIOXIDE, HYDROGRAPHIC, AND CHEMICAL DATA OBTAINED DURING THE R/V KNORR CRUISES IN THE NORTH ATLANTIC OCEAN ON WOCE SECTIONS AR24 (NOVEMBER 2-DECEMBER 5, 1996) AND A24, A20, AND A22
}

(MAY 30-SEPTEMBER 3, 1997)

\author{
Contributed by \\ Kenneth M. Johnson, ${ }^{1}$ Robert M. Key, ${ }^{2}$ Frank J. Millero, ${ }^{3}$ Christopher L. Sabine, ${ }^{4}$ \\ Douglas W. R. Wallace, ${ }^{5}$ Christopher D. Winn, ${ }^{6}$ Linda Arlen, ${ }^{7}$ Kenneth Erickson, ${ }^{8}$ \\ Karsten Friis, ${ }^{5}$ Meridith Galanter, ${ }^{3}$ Jamie Goen, ${ }^{3}$ Richard Rotter, ${ }^{2}$ Carrie Thomas, ${ }^{2}$ \\ Richard Wilke, ${ }^{8}$ Taro Takahashi, ${ }^{9}$ and Stewart C. Sutherland ${ }^{9}$ \\ ${ }^{1}$ Department of Applied Science, Brookhaven National Laboratory, Upton, NY, U.S.A. \\ Retired, now at P.O. Box 483, Wyoming, RI, U.S.A. \\ ${ }^{2}$ Department of Geosciences, Princeton University, Princeton, NJ, U.S.A. \\ ${ }^{3}$ Rosenstiel School of Marine and Atmospheric Science, University of Miami, Miami, FL, U.S.A. \\ ${ }^{4}$ Pacific Marine Environmental Laboratory, NOAA, Seattle, WA, U.S.A. \\ ${ }^{5}$ Institute for Marine Sciences, Kiel, Germany \\ ${ }^{6}$ Hawaii Pacific University, Kaneohe, HI, U.S.A. \\ ${ }^{7}$ James J. Howard Laboratory, NOAA, Sandy Hook, NJ, U.S.A. \\ ${ }^{8}$ Department of Applied Science, Brookhaven National Laboratory, Upton, NY, U.S.A. \\ ${ }^{9}$ Lamont-Doherty Earth Observatory, Palisades, NY, U.S.A.
}

\author{
Prepared by \\ Alexander Kozyr \\ Carbon Dioxide Information Analysis Center \\ Oak Ridge National Laboratory \\ Oak Ridge, Tennessee, U.S.A.
}

Date Published: September 2003

Prepared for the

Climate Change Research Division

Office of Biological and Environmental Research

U.S. Department of Energy

Budget Activity Numbers KP 1204010 and KP 1202030

Prepared by the

Carbon Dioxide Information Analysis Center

OAK RIDGE NATIONAL LABORATORY

Oak Ridge, Tennessee 37831-6335

managed by

UT-BATTELLE, LLC

for the

U.S. DEPARTMENT OF ENERGY

under contract DE-AC05-00OR22725 



\section{CONTENTS}

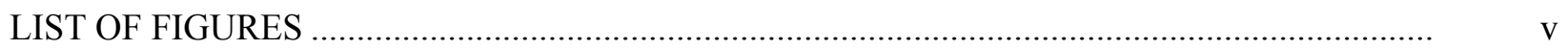

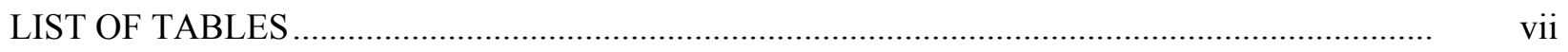

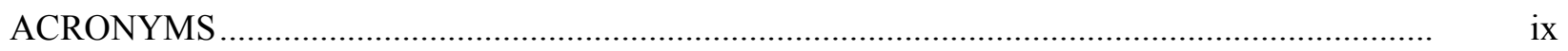

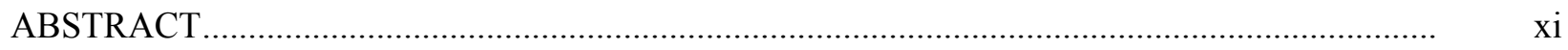

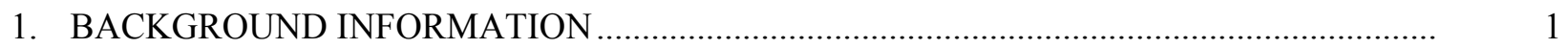

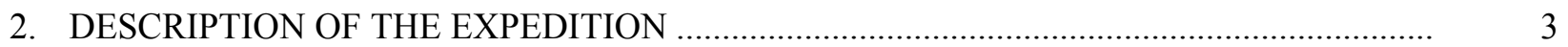

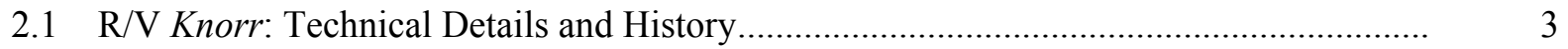

2.2 The North Atlantic Ocean $\mathrm{CO}_{2}$ Survey Cruises Information ......................................... 5

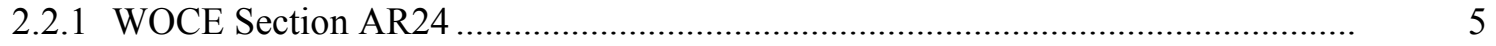

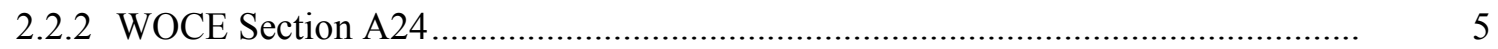

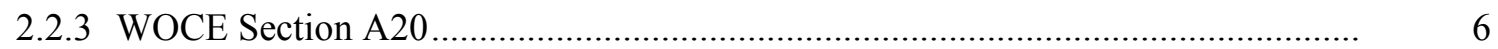

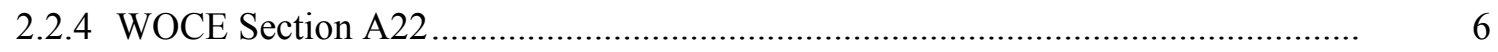

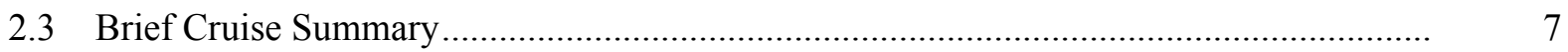

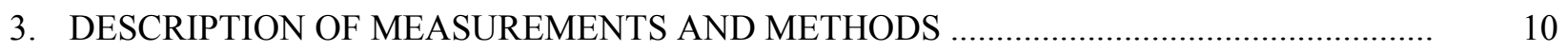

3.1 Hydrographic Measurements ..................................................................................... 10

3.1.1 SIO/Ocean Data Facility Methods and Instrumentation (Section A24)....................... 10

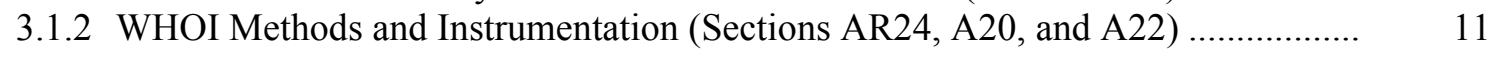

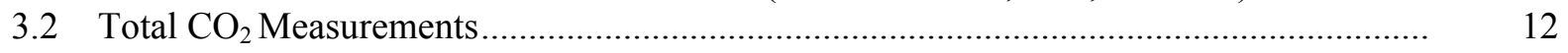

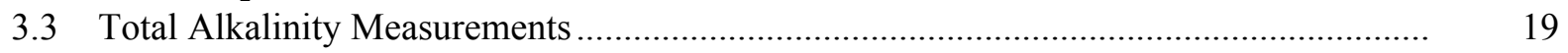

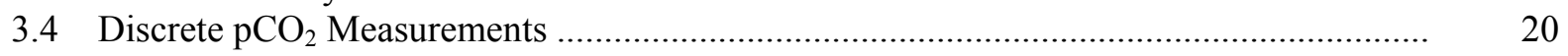

4. DATA CHECKS AND PROCESSING PERFORMED BY CDIAC ........................................ 24

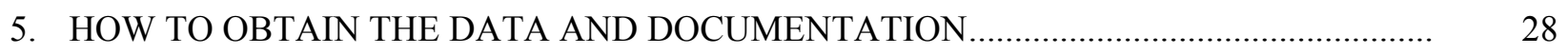

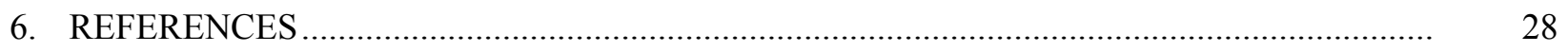

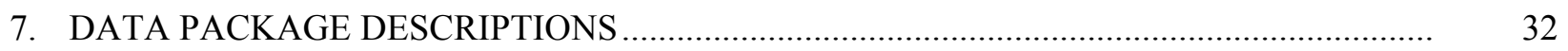

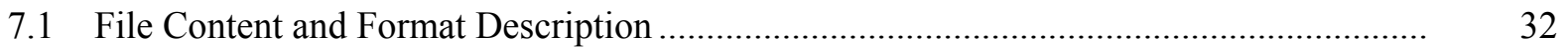

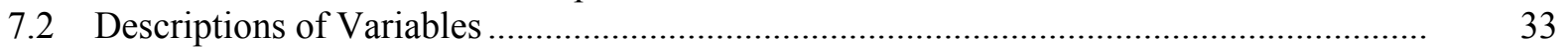





\section{LIST OF FIGURES}

Figure

Page

1 The cruise tracks during the North Atlantic survey expeditions along WOCE

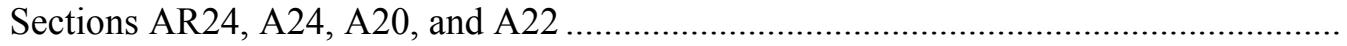

2 The temporal distribution of differences between the measured and certified $\mathrm{TCO}_{2}$ for CRM analyzed on SOMMA-coulometry systems 004 (closed circles) and 030 (open circles) during the WOCE North Atlantic Section AR24 in 1996

3 The temporal distribution of differences among the measured and certified $\mathrm{TCO}_{2}$ for CRM analyzed on SOMMA-coulometry systems 004 (closed circles) and 030 (open circles) and 006 (shaded diamonds) during the WOCE North Atlantic Sections A24, A20, and A22 in 1997

$4 \quad$ Schematic diagram for the equilibrator-IR system used for the $\mathrm{pCO}_{2}$ determination in discrete seawater samples.....

5 Example of Ocean Data View station mode plot: Measurements vs depth for Stations 45-48 of Section A20

6 Distribution of $\mathrm{TCO}_{2}$ in seawater along WOCE Section A20

7 Property-property plots for all stations occupied during the R/V Knorr cruise along WOCE Section A20 



\section{LIST OF TABLES}

Table

Page

1 Technical characteristics of the R/V Knorr

2 The "to-deliver" pipette volume $\left(\mathrm{V}_{\text {cal }}\right)$ and calibration temperature $\left(\mathrm{t}_{\text {cal }}\right)$ for the discrete SOMMA-Coulometer Systems (S/N 004 and 030) used on WOCE Section AR24 (1996) and Sections A24, A20, and A22 (1997)

3 The electronic calibration and the mean gas calibration coefficients for the discrete $\mathrm{TCO}_{2}$ systems on WOCE Section AR24 (1996) and Sections A24, A20, and A22 (1997)

4 The mean analytical difference $\left(\Delta \mathrm{TCO}_{2}=\right.$ measured-certified $)$ and the standard deviation of the differences between measured and certified $\mathrm{TCO}_{2}$ on WOCE Sections AR24, A24, A20, and A22.

5 Precision of the discrete $\mathrm{TCO}_{2}$ analyses on WOCE Sections A24, A20, and $\mathrm{A} 22$

6 The mean analytical difference between analyzed and certified TALK for the MATS on WOCE Sections AR24 (1996), and Sections A24, A20, and A22 (1997)

7 Content, size, and format of data files 



\section{ACRONYMS}

ACCE

A/D

ADCP

ALACE

BOD

BNL

${ }^{14} \mathrm{C}$

CALFAC

CDIAC

CFC

CMDL

$\mathrm{CO}_{2}$

CTD

CRM

DOE

emf

EXPOCODE

FTP

GMT

GPS

IAPSO

I/O

IR

JGOFS

kn

LADCP

LDEO

MATS

NBIS

NDP

NOAA

$\mathrm{nm}$

NSF

ODF

ODV

ORNL

OSU

$\mathrm{PC}$

PDF

PI

PU

QA

QC

$\mathrm{R} / \mathrm{V}$

RSMAS

SIO

SOMMA

SSW

TALK
Atlantic Circulation and Climate Change Experiment

analog-to-digital

acoustic Doppler current profiler

autonomous Lagrangian circulation explorer

biological oxygen demand

Brookhaven National Laboratory

radiocarbon

calibration factor

Carbon Dioxide Information Analysis Center

chlorofluorocarbon

Climate Monitoring and Diagnostics Laboratory

carbon dioxide

conductivity, temperature, and depth sensor

certified reference material

U.S. Department of Energy

electro-magnetic fields

expedition code

file transfer protocol

Greenwich mean time

global positioning system

International Association for the Physical Sciences of the Ocean

input-output

infrared

Joint Global Ocean Flux Study

knots

lower ADCP

Lamont-Doherty Earth Observatory

Miami University alkalinity titration systems

Neil Brown Instrument system

numeric data package

National Oceanic and Atmospheric Administration

nautical mile

National Science Foundation

Ocean Data Facility

Ocean Data View

Oak Ridge National Laboratory

Oregon State University

personal computer

Portable Document Format

principal investigator

Princeton University

quality assurance

quality control

research vessel

Rosenstiel School of Marine and Atmospheric Sciences

Scripps Institution of Oceanography

single-operator multiparameter metabolic analyzer

standard seawater

total alkalinity 
$\mathrm{TCO}_{2}$

TD

UH

UM

UW

VFC

WHOI

WHPO

WOCE

WHP total carbon dioxide

to-deliver

University of Hawaii

University of Miami

University of Washington

voltage to frequency converter

Woods Hole Oceanographic Institution

WOCE Hydrographic Program Office

World Ocean Circulation Experiment

WOCE Hydrographic Program 


\begin{abstract}
Johnson K., R. Key, F. Millero, C. Sabine, D. Wallace, C. Winn, L. Arlen, K. Erickson, K. Friis, M. Galanter, J. Goen, R. Rotter, C. Thomas, R. Wilke, T. Takahashi, and S. Sutherland. 2003. Carbon Dioxide, Hydrographic, and Chemical Data Obtained During the R/V Knorr Cruises in the North Atlantic Ocean on WOCE Sections AR24 (November 2-December 5, 1996) and A24, A20, and A22 (May 30-September 3, 1997) A. Kozyr (ed.) ORNL/CDIAC-143, NDP-082. Carbon Dioxide Information Analysis Center, Oak Ridge National Laboratory, U.S. Department of Energy, Oak Ridge, Tennessee, 41 pp.
\end{abstract}

This documentation describes the procedures and methods used to measure total carbon dioxide $\left(\mathrm{TCO}_{2}\right)$ total alkalinity (TALK), and partial pressure of $\mathrm{CO}_{2}\left(\mathrm{pCO}_{2}\right)$ at hydrographic stations on the North Atlantic Ocean sections AR24, A24, A20, and A22 during the R/V Knorr Cruises 147-2, 151-2, 151-3, and 151-4 in 1996 and 1997. Conducted as part of the World Ocean Circulation Experiment (WOCE), the expeditions began at Woods Hole, Massachusetts, on October 24, 1996, and ended at Woods Hole on September 3, 1997. Instructions for accessing the data are provided.

A total of 5,614 water samples were analyzed for discrete $\mathrm{TCO}_{2}$ using two single-operator multiparameter metabolic analyzers (SOMMAs) coupled to a coulometer for extracting and detecting $\mathrm{CO}_{2}$. The overall accuracy of the $\mathrm{TCO}_{2}$ determination was $\pm 1.59 \mu \mathrm{mol} / \mathrm{kg}$. The TALK was determined in a total of 6,088 discrete samples on all sections by potentiometric titration using an automated titration system developed at the University of Miami. The accuracy of the TALK determination was $\pm 3 \mu \mathrm{mol} / \mathrm{kg}$. A total of 2,465 discrete water samples were collected for determination of $\mathrm{pCO}_{2}$ in seawater on sections $\mathrm{A} 24, \mathrm{~A} 20$, and $\mathrm{A} 22$. The $\mathrm{pCO}_{2}$ was measured by means of an equilibrator-IR system by scientists from Lamont-Doherty Earth Observatory. The precision of the measurements was estimated to be about \pm $0.15 \%$, based on the reproducibility of the replicate equilibrations on a single hydrographic station.

The North Atlantic data set is available as a numeric data package (NDP) from the Carbon Dioxide Information Analysis Center. The NDP consists of 12 ASCII data files, one Ocean Data View-formatted data file, a NDP-082 ASCII text file, a NDP-082 PDF file, and this printed documentation, which describes the contents and format of all files, as well as the procedures and methods used to obtain the data.

Keywords: carbon dioxide; $\mathrm{TCO}_{2}$; total alkalinity; partial pressure of $\mathrm{CO}_{2}$; coulometry; gas chromatography; World Ocean Circulation Experiment; North Atlantic Ocean; hydrographic measurements; carbon cycle. 



\section{BACKGROUND INFORMATION}

The World Ocean Circulation Experiment (WOCE) Hydrographic Program (WHP) was a major component of the World Climate Research Program. The primary WOCE goal was to understand the general circulation of the global ocean well enough to be able to model its present state and predict its evolution in relation to long-term changes in the atmosphere. The impetus for the carbon system measurements arose from concern over the rising atmospheric concentrations of carbon dioxide $\left(\mathrm{CO}_{2}\right)$. Increasing atmospheric $\mathrm{CO}_{2}$ may intensify the earth's natural greenhouse effect and alter the global climate.

Although $\mathrm{CO}_{2}$-related measurements [total $\mathrm{CO}_{2}\left(\mathrm{TCO}_{2}\right)$, total alkalinity (TALK), partial pressure of $\mathrm{CO}_{2}\left(\mathrm{pCO}_{2}\right)$, and $\left.\mathrm{pH}\right]$ were not official WOCE measurements, a coordinated effort to make the carbon measurements was supported as a core component of the Joint Global Ocean Flux Study (JGOFS). This effort received support in the United States from the U.S. Department of Energy (DOE), the National Oceanic and Atmospheric Administration (NOAA), and the National Science Foundation (NSF) for WOCE cruises through 1998 to measure the global spatial and temporal distributions of $\mathrm{CO}_{2}$ and related parameters. Goals were to estimate the meridional transport of inorganic carbon in a manner analogous to the oceanic heat transport (Bryden and Hall 1980; Brewer, Goyet, and Drysen 1989; Holfort et al. 1998; Roemmich and Wunsch 1985) and to build a database suitable for carbon-cycle modeling and the estimation of anthropogenic $\mathrm{CO}_{2}$ increase in the oceans. The $\mathrm{CO}_{2}$ survey took advantage of the sampling opportunities provided by the WOCE cruises during this period, and the final data set was expected to cover on the order of 23,000 stations. Wallace (2002) recently reviewed the goals, conduct, and initial findings of the survey.

This report discusses the results of the research vessel (R/V) Knorr expedition along the WOCE Sections AR24, A24, A20, and A22 [cruises 147-2, 151-2, 151-3, and 151-4, respectively (Fig. 1)]. The latter three cruises not only were part of WOCE but also were a component of the Atlantic Circulation and Climate Change Experiment (ACCE). The ACCE was intended to improve the understanding of the entrainment and transformation of warm saline subtropical water into the subpolar North Atlantic waters, with special emphasis on sampling the North Atlantic Current region. This region plays an important role in the exchange of $\mathrm{CO}_{2}$ between the subtropical and subpolar gyres. The exchange between these gyres affects the magnitude and direction of air-sea $\mathrm{CO}_{2}$ exchange in the North Atlantic and is therefore an important factor in the global carbon cycle. By 1997 the goal of high-quality measurements of chemical and physical parameters had been completed in all of the major oceans except the North Atlantic. Hence the cruises documented here also represent the concluding phase of the DOE-sponsored Global $\mathrm{CO}_{2}$ Survey.

The expedition (section AR24) started at Woods Hole, Massachusetts, USA, on October 24, 1996, with a transit to the Azores; the station work began on November 2, 1996. The 1997 cruises started from Ponta Delgada, Azores, on May 30, 1997, and ended in Woods Hole on September 3, 1997, after stops in Halifax, N.S., Canada, and Port of Spain, Trinidad. The large-scale three-dimensional distribution of temperature, salinity, and chemical constituents, including the carbonate system parameters measured on these cruises $\left(\mathrm{TCO}_{2}\right.$, and TALK on the AR24 section and $\mathrm{TCO}_{2}, \mathrm{TALK}$, and $\mathrm{pCO}_{2}$ on A24, A20, and A22 sections), will be plotted using the data from these sections. Knowledge of these parameters and their initial conditions will enable researchers to determine heat and water transport, as well as carbon transport, which will contribute to the understanding of processes affecting climate change. The sections described in this report include WOCE Section A22, the only Caribbean transect of the WOCE program. In addition, the stations occupied on these cruises repeat some sections sampled during the International Geophysical Year during the 1950s. They also include measurements from the eastern subpolar gyre of source and overflow waters from the Labrador, Norwegian, Greenland, and Iceland Seas. They give good

coverage of boundary currents, particularly the Deep Western Boundary Current; and repeating AR24 and A24 provides some insight into seasonal variation in the North Atlantic. 




Fig. 1. The cruise tracks during the North Atlantic survey expeditions along WOCE Sections AR24, A24, A20, and A22. 
This data documentation is the result of the cooperative efforts of chemical oceanographers from Brookhaven National Laboratory (BNL), the University of Hawaii (UH), Lamont-Doherty Earth Observatory (LDEO), and the University of Miami's Rosenstiel School of Atmospheric and Marine Science (RSMAS), U.S.A. The work aboard the R/V Knorr was supported by DOE under contract DEACO2-76CH00016 and DE-FG02-93ER61540. The authors are also especially grateful to the Sonderforschungsbereich 460 at the University of Kiel (Dr. F. Schott, Leader), funded by the Deutsche Forschungsgemeinschaft, for their support and assistance in completing the written documentation.

\section{DESCRIPTION OF THE EXPEDITION}

\subsection{R/V Knorr: Technical Details and History}

The R/V Knorr, built in 1969 by the Defoe Shipbuilding Company in Bay City, Michigan, is owned by the U.S. Navy. It was turned over to the Woods Hole Oceanographic Institution (WHOI) in 1971 for operation under a charter agreement with the Office of Naval Research. It was named for E. R. Knorr, a hydrographic engineer and cartographer who in 1860 held the title of Senior Civilian and Chief Engineer Cartographer of the U.S. Navy Office. Its original length and beam were 245 and $46 \mathrm{ft}$, respectively. Beginning on February 6, 1989, it underwent a major midlife retrofit or "jumbo-izing" at the McDermott Shipyard in Amelia, Louisiana. A midsection was added to the ship to stretch its length by $34 \mathrm{ft}$, to $279 \mathrm{ft}$, and fore and aft azimuthing propulsion systems were added to make it one of the most maneuverable and stable ships in the oceanographic fleet. By the time it was returned to WHOI in late 1991, the retrofit had taken 32 months. The WOCE section P6 was the vessel's first scientific cruise after the retrofitting. The $\mathrm{R} / \mathrm{V}$ Knorr was designed for a wide range of oceanographic operations and possesses antiroll tanks and a strengthened bow for duty in icy waters. Like its sister ship, the R/V Melville, it is used for ocean research and routinely carries scientists from many different countries. Table 1 provides a list of technical

characteristics of the R/V Knorr. 
Table 1. Technical characteristics of the R/V Knorr

Ship name:

Call sign:

Basic dimensions:

Gross registered tonnage

Overall length

Draught (maximum)

Maximum speed

Main deck clear length
R/V Knorr

KCEJ
$2518 \mathrm{~T}$

$279 \mathrm{ft}$

$16.5 \mathrm{ft}$

$14.5 \mathrm{kn}$

$126 \mathrm{ft}$
Displacement

Beam

Service speed

Minimum speed
$2958 \mathrm{LT}$

$46 \mathrm{ft}$

$12 \mathrm{kn}$

$0.1 \mathrm{kn}$
Personnel:

$\begin{array}{ll}\text { Crew } & 24 \\ \text { Scientists } & 34\end{array}$

Main engine:

$4 \times$ Mak6M $322=4 \times 1000 \mathrm{~kW}$ at $750 \mathrm{rpm}$

Propulsion:

Twin lips diesel-electric, azimuthing stern thrusters, 1500 SHP

Bow thruster:

Lips retractable azimuthing 900 SHP

Fuel capacity:

$160,500 \mathrm{gal}$

Maximum cruise duration:

60 days $(12,000 \mathrm{~nm})$

Nautical equipment:

Integrated navigation system

Potable water generator

2 instrument hangars

Winches: 1 heavy-duty trawl with $30,000 \mathrm{ft}$ of $1 / 2$-in. wire

2 hydrographic, both with $30,000 \mathrm{ft}$ of hydrowire

Hydraulic cranes on the starboard side aft and midships

Scientific storage space of $1,320 \mathrm{ft}^{2}$

Portable van space

Machine shop

Fume hoods

Uninterruptible power supply

Air conditioning

Library/lounge

$3680 \mathrm{ft}^{2}$ of laboratory space for multidisciplinary research 


\subsection{The North Atlantic Ocean $\mathrm{CO}_{2}$ Survey Cruises Information}

\subsubsection{WOCE Section AR24}

Ship name:

Expocode

Cruise/Leg:

Ports of call:

Dates:

Funding support:

Chief scientist:

\author{
R/V Knorr \\ $316 \mathrm{~N} 147-2$ \\ 147-2/A24R \\ Ponta Delgada, The Azores \\ November 2, 1996-December 5, 1996 \\ DOE, NSF \\ Dr. Mike McCartney, WHOI
}

Parameters measured, institution, and responsible investigators

\begin{tabular}{lll} 
Parameter & Institution & Responsible investigators \\
\hline $\mathrm{CTD}^{1}$, Salinity & WHOI & M. McCartney \\
Nutrients & WHOI & M. McCartney \\
Oxygen & WHOI & M. McCartney \\
$\mathrm{CFCs}^{2}$ & SIO & R. Weiss \\
Tritium, helium & LDEO & P. Schlosser \\
$\mathrm{TCO}_{2}$ & UH/BNL & R. Rotter, C. Winn, K. M. Johnson \\
$\mathrm{TALK}^{\text {Underway } \mathrm{pCO}_{2}}$ & RSMAS & M. Galanter, J. Goen, F. Millero \\
${ }^{14} \mathrm{C}$ & AOML & R. Wanninkhof \\
$\mathrm{ADCP}^{3} / \mathrm{LADCP}^{4}$ & PU & R. Key, R. Rotter \\
& UH & E. Firing
\end{tabular}

\subsubsection{WOCE Section A24}

Ship Name

Expocode

Cruise / Leg

Ports of call

Dates

Funding support

Chief Scientist

\author{
R/V Knorr \\ $316 \mathrm{~N} 151-2$ \\ $151-2 / A 24$ \\ Ponta Delgado, St. Michael, Azores; Halifax, N.S., Canada \\ May 30, 1997-July 5, 1997 \\ DOE, NSF \\ Dr. Lynne Talley, SIO
}

Parameters measured, institution, and responsible investigators

\begin{tabular}{lll} 
Parameter & Institution & Responsible investigators \\
\hline CTD, salinity & SIO & L. Talley, F. Delahoyde, C. Mattson \\
Nutrients & SIO/ODF & J. Swift, D. Masten, S. Becker \\
Oxygen & SIO/ODF & J. Swift, J. Boaz \\
CFCs & SIO & R. Weiss, F. Van Woy, M. Vollmer \\
Tritium, helium & LDEO & P. Schlosser, D. Smith, S. Khatiwala \\
$\mathrm{TCO}_{2}$ & BNL & D. Wallace, K. Johnson, L. Arlen \\
$\mathrm{TALK}_{\text {pCO }}$, discrete & RSMAS & F. Millero, M. Galanter, J. Goen \\
Underway pCO ${ }_{2}$ & LDEO & T. Takahashi, A. Wilson \\
${ }^{14} \mathrm{C}$ & SIO & R. Weiss, F. Van Woy \\
ADCP/LADCP & PU & R. Key, R. Rotter \\
& UH & E. Firing
\end{tabular}




\subsubsection{WOCE Section A20}

$\begin{array}{ll}\text { Ship name } & \text { R/V Knorr } \\ \text { Expocode } & \text { 316N151_3 } \\ \text { Cruise/leg } & \text { 151-3/A20 } \\ \text { Ports of call } & \text { Halifax, N.S, Canada, Port of Spain, Trinidad } \\ \text { Dates } & \text { July 17, 1997-August 10, 1997 } \\ \text { Funding support } & \text { DOE, NSF } \\ \text { Chief scientist } & \text { Dr. Robert Pickart, WHOI }\end{array}$

\section{Parameters measured, institution, and responsible investigators}

\begin{tabular}{lll} 
Parameter & Institution & Responsible investigators \\
\hline CTD, salinity & WHOI & R. Pickart, M. Swartz \\
Nutrients & OSU & L. Gordon, J. Jennings, B. Sullivan \\
Oxygen & WHOI & R. Pickart \\
CFCs & LDEO & W. Smethie, E. Gorman, L. Baker, D. Chaky \\
Tritium, helium & WHOI & W. Jenkins, P. Landry, S. Birdwhiste \\
$\mathrm{TCO}_{2}$ & BNL & D. Wallace, R. Wilke, K. Erickson, K. M. Johnson \\
$\mathrm{pCO}_{2}$, discrete & LDEO & T. Takahashi, J. Goddard \\
$\mathrm{TALK}_{\text {Underway } \mathrm{pCO}_{2}}$ & RSMAS & F. Millero, C. Sabine, C. Thomas \\
${ }^{14} \mathrm{C}$ & SIO & R. Weiss \\
Bio-optics & PU & R. Key, C. Sabine, C. Thomas \\
Halocarbons & LDEO & C. Knudson \\
ADCP/LADCP & DU & R. Moore, P. Morneau, W. Groszko \\
ALACE 5 floats & UW & D. Torres
\end{tabular}

\subsubsection{WOCE Section A22}

Ship name

Expocode

Cruise/leg

Ports of call

Dates

$\mathrm{CO}_{2}$ funding support

Chief scientist

\section{Knorr}

$315 \mathrm{~N} 1514$

151-4/A22)

Port of Spain, Trinidad; Woods Hole, MA, USA

August 15, 1997-September 3, 1997

DOE, NSF

Dr. Terrence Joyce, WHOI

\section{Parameters measured, institution, and responsible investigators}

\begin{tabular}{lll} 
Parameter & Institution & Responsible investigators \\
\hline CTD, salinity & WHOI & T. Joyce, G. Knapp, L. Stein \\
Nutrients & OSU & L. Gordon, A. Ross, J. Arrington \\
Oxygen & WHOI & G. Knapp, D. Wellwood \\
CFCs & LDEO & W. Smethie, L. Baker, D. Chaky, E. Gorman, R. Swartz \\
Tritium, helium & WHOI & W. Jenkins, J. Curtis, P. Landry \\
$\mathrm{TCO}_{2}$ & BNL & D. Wallace, K. M. Johnson, K. Erickson \\
$\mathrm{pCO}_{2}$, discrete & LDEO & T. Takahashi, A. Wilson \\
Underway pCO $\mathrm{pC}_{2}$ & SIO & R. Weiss \\
$14 \mathrm{C}$ & PU & R. Key, C. Thomas, R. Rotter
\end{tabular}




$\begin{array}{lll}\text { ADCP, LADCP } & \text { WHOI } & \text { F. Bahr } \\ \text { Halocarbons } & \text { DU } & \text { W. Groszko } \\ \text { pALACE floats } & \text { UW } & \text { D. Swift } \\ \text { Observer } & \text { Venezuela } & \text { Antonio Perez-Aguirre }\end{array}$

${ }^{1}$ CTD-conductivity, temperature, and depth sensor

${ }^{2} \mathrm{CFC}$-clorofluorocarbon

${ }^{3} \mathrm{ADCP}-$ acoustic Doppler current profiler

${ }^{4}$ LADCP-lower ADCP

${ }^{5}$ ALACE-autonomous Lagrangian circulation explorer

\section{Participating institutions}

$\begin{array}{ll}\text { AOML } & \text { Atlantic Oceanographical and Meterological Laboratory } \\ \text { BNL } & \text { Brookhaven National Laboratory } \\ \text { LDEO } & \text { Lamont-Doherty Earth Observatory } \\ \text { UH } & \text { University of Hawaii } \\ \text { OSU } & \text { Oregon State University } \\ \text { PU } & \text { Princeton University } \\ \text { RSMAS } & \text { Rosensteil School of Marine and Atmospheric Science, University of Miami } \\ \text { SIO } & \text { Scripps Institution of Oceanography } \\ \text { SIO/ODF } & \text { Ocean Data Facility Scripps Institution of Oceanography } \\ \text { UW } & \text { University of Washington } \\ \text { WHOI } & \text { Woods Hole Oceanographic Institution } \\ \text { DU } & \text { Dalhousie University }\end{array}$

\subsection{Brief Cruise Summary}

For the section AR24 (cruise 147-2), the $\mathrm{TCO}_{2}$ and TALK systems were placed on board and set up on the R/V Knorr in Woods Hole, Massachusetts, during the period October 21-24, 1996, by the University of Miami TALK and the UH/BNL $\mathrm{TCO}_{2}$ measurement groups. The systems were successfully tested, and the Knorr departed Woods Hole on October 24 for the Azores with Mike McCartney as chief scientist. C. Winn was the $\mathrm{CO}_{2}$ group leader during the transit to the Azores and was present when one of the benches supporting one of the SOMMA-coulometer systems broke loose, threatening to destroy the analytical system. Fortunately, the analytical equipment suffered only minor damage, and the minor repairs required were completed by the time the ship was ready to begin the AR2 4 section. C. Winn left the ship in the Azores and was replaced by R. Rotter, A. Adams, and J. Tegeder, with R. Rotter serving as the group leader. The ship departed on the AR24 cruise from Ponta Delgada on November 1, 1996. The cruise track was, with minor deviations, basically a winter version of the two transoceanic A24 sections completed during the summer of 1997 (see Fig. 1).

During the AR24 section, the principal problem with the $\mathrm{TCO}_{2} \mathrm{SOMMA}$ systems Nos. 004 and 030 was the malfunctioning of the solenoid pinch valves used to dispense the sample. Some were damaged and ceased to work, while others were sensitive to power fluctuations and worked intermittently.

Replacement valves were quickly consumed, so that SOMMA system No.30 became the primary system. As a consequence, the bulk of the sample $\mathrm{TCO}_{2}$ analyses completed during the AR2 4 section (see Table 4 in Sect. 3.2) were made on system 030. These problems also resulted in the sampling of 10 fewer stations for $\mathrm{TCO}_{2}$ than for TALK during the cruise, with most of the discrepancies occurring between November 14 and 20, 1996. After the concluding station 176 on December 2, 1996, the Knorr docked in South Hampton, United Kingdom, on December 3, 1996.

Following the AR24 section, the analytical systems were repaired and re-calibrated. They were then set up on the R/V Knorr in Woods Hole during the week of May 13-19, 1997, by the University of 
Miami TALK and the $\mathrm{BNL} \mathrm{TCO}_{2}$ measurement groups. Three SOMMA-coulometer systems and three TALK titrators were set up for the three WOCE sections (A24, A20, and A22). In addition to the discrete $\mathrm{TCO}_{2}$ systems ( $\mathrm{S} / \mathrm{Ns} 004$ and 030 ), a third system (S/N 006) was set up for underway surface $\mathrm{TCO}_{2}$ measurements. The equilibrator-infrared (IR) gas analyzer system for the determination of partial pressure of $\mathrm{CO}_{2}\left(\mathrm{pCO}_{2}\right)$ in discrete sea water samples was set up by the scientists from LDEO. The discrete $\mathrm{TCO}_{2}$ systems were successfully calibrated using both $\mathrm{CO}_{2}$ calibration gas and the certified reference material (CRM) on May 17, 1997, while the calibration of the underway system (006) was completed on May 30. The Knorr departed Woods Hole on May 20 (Leg 151_1) with Dr. Tom Rossby as chief scientist. The TALK group remained onboard to test the instruments on the "shake-down" transit from Woods Hole to the embarkation point for Leg 151-2, Ponta Delgada on the island of St. Michael, Azores.

Some 300 underway surface samples were drawn and analyzed for TALK during the shake-down cruise, but these data are not reported to the Carbon Dioxide Information Analysis Center (CDIAC). Greg Eischeid of WHOI completed the plumbing connections between the ship's underway intake and the underway SOMMA (006). After correcting some minor problems, he obtained the required flow of $1 \mathrm{~L} / \mathrm{min}$ through the underway system. Problems with operating the underway pipette were also encountered, but they were eliminated by software changes coordinated through BNL, so that by the time the ship arrived in Ponta Delgada, the underway system was operational. The most serious problem with the discrete $\mathrm{TCO}_{2}$ systems was that an erratic transmission reading with the system 030 coulometer made titrations impossible. This program was temporarily corrected by "jiggling" the voltage-to-frequency converter (VFC) and ensuring that all associated chips were properly seated. System 004 was tested successfully during the shake-down cruise, which ended on May 29, 1997, in Ponta Delgada.

K. M. Johnson departed JFK Airport in New York on May 27, 1997, for Ponta Delgada via Lisbon and arrived on May 28 in the Azores, where he joined L. Arlen, who was already in Ponta Delgada. The TALK and $\mathrm{TCO}_{2}$ measurement groups moved onboard ship on May 29 and readied the systems for the following day, when the ship departed Ponta Delgada on section A24 with Dr. Lynne Talley as chief scientist. Sample analysis began on system 004 immediately, but the system 030 coulometer once again exhibited unstable erratic transmission readings and was immediately replaced with the back-up unit. Sample analysis with this unit began on May 31, 1997.

The cruise track for section A24 was basically rectangular, encompassing four separate sections (see Fig. 1) starting and ending in the Azores. The first section began at Terceira, Azores, proceeding northeastward toward the Goban Spur and crossing the Mediterranean Water/Labrador Sea Water mixing zone obliquely. Upon completion of the first section, the ship was diverted to Cork, Ireland, for an emergency exchange of crew members. The second section crossed the southern Rockall Trough, from Porcupine Bank to the southern end of the Rockall Bank. The third section crossed the northern part of the subpolar gyre, from the Hebrides to Rockall Bank, to Hatton Bank, to the Reykjanes Ridge and to Greenland near Angmassalik, crossing the Rockall Trough just north of the Anton Dohrn Seamount. Ice conditions at Greenland were favorable, and sampling was completed at stations well onto the shelf (average depth $500 \mathrm{~m}$ ). After a transit southward to Cape Farewell, Greenland, the fourth section began at Cape Farewell and proceeded southeastward to the Charlie Gibbs Fracture Zone and then back to Terceira with the last Station on June 28, 1997. After a 6-day transit, the ship docked in Halifax, Nova Scotia, on July 5 .

The weather remained uniformly good throughout Leg A24, and all carbonate measurement systems were operated essentially without major problems. Perhaps the biggest disappointment was the failure to rendezvous with the nearby R/V Meteor in early June for a social gathering. Some 153 hydrographic stations were occupied during $\mathrm{A} 24 . \mathrm{TCO}_{2}$ was measured on 92 of these stations and TALK was measured on 90 . Therefore, roughly $60 \%$ of the stations occupied on this cruise were sampled for TALK and $\mathrm{TCO}_{2}$. This proportion was somewhat higher than the $50 \%$ of stations sampled on typical WOCE cruises as a result of an accelerated frequency of sampling. The increased frequency was brought about by making the A24 station interval dependent on bathymetry, which often varied radically over distances much less than the proscribed WOCE station interval of $30 \mathrm{~nm}$. The carbon group sampled as many stations as possible given the limits imposed by the length of time required for the $\mathrm{TCO}_{2}$ and $\mathrm{TALK}$ determinations. In 
addition, discrete surface samples were taken at most stations, and the underway system was operated continuously on Section A24. Originally the A24 section was scheduled to terminate in St. Johns, but because repairs were required, the Knorr put into Halifax on July 4, 1997. An attempt was made to arrange for a back-up coulometer or to repair the damaged coulometer before the next cruise.

Unfortunately, this did not work out, and scientists were still left without a back-up coulometer for the coming cruises.

Because of the delay for repairs in Halifax, no direct handoff between $\mathrm{CO}_{2}$ measurement crews was made. The $\mathrm{TCO}_{2}$ relief team consisting of Rick Wilke and Ken Erickson arrived well after the first crew had left and just prior to the Knorr's departure on July 17, 1997, on section A20. However, Wilke had been briefed at BNL concerning the performance of the $\mathrm{TCO}_{2}$ systems and possible problems due to depowering of the ship during the repairs. The relief crew for TALK consisted of Chris Sabine and Carrie Thomas, who were also responsible for the ${ }^{14} \mathrm{C}$ samples.

The Knorr left Halifax bound for Port of Spain, Trinidad, on July 17, 1997, with Dr. Robert Pickart as chief scientist and 31 other scientists. From July 17 until August 10, 1997, except for a couple of dog legs across the shelf regions, the Knorr occupied a series of stations in a straight line from the Newfoundland Shelf to the Suriname Shelf along approximately $52^{\circ} \mathrm{W}$ (WOCE Section A20). This Section is also a part of the ACCE and one of two North Atlantic WOCE meridional long-lines (the second long-line, A22, was visited during the subsequent cruise). In the early days of the cruise, heavy fog off the Grand Banks made for slow going. Otherwise, the excellent weather experienced during the cruise allowed for the sampling of 95 hydrographic stations, which was more than planned. After the initial test station in $3000 \mathrm{~m}$ at $57^{\circ} \mathrm{W}$, the ship steamed to the $1000-\mathrm{m}$ isobath and the work commenced. During A20, the water masses sampled included the slopewaters, the Laborador Current, the Labrador Sea Water, the Deep Western Boundary Current, the Gulf Stream with a warm core ring, the Sargasso Sea, and finally, as the ship turned toward Trinidad, the North Brazil Current system. On the depths less than $1000 \mathrm{~m}$, a 24-position conductivity, temperature, and depth (CTD) sensor was used, while for greater depths, a 36-position CTD was used. Hydographic station intervals ranged from $3 \mathrm{~nm}$ on the shelf, to $10-15 \mathrm{~nm}$ across the slopes, to $15-25 \mathrm{~nm}$ across the Gulf Steam and $40 \mathrm{~nm}$ in the Sargasso Sea. Other physical oceanographic tasks completed included the deployment of 11 floats and drifters and the deployment or recovery of 4 moorings. The $\mathrm{TCO}_{2}$ systems 004 and 006 continued to operate well, but system 030 required the replacement of one pinch valve and a faulty isolation valve on July 19. Thereafter, this instrument functioned satisfactorily. The Knorr arrived in Port of Spain, Trinidad, on August 10, 1997.

$\mathrm{K}$. Johnson left New York on August 12 to relieve R. Wilke of the $\mathrm{TCO}_{2}$ measurement group, while K. Erickson and C. Thomas remained on board to continue the $\mathrm{TCO}_{2}$ and TALK measurements for the next section A22.

The Knorr departed Port of Spain at 9 A.M. on August 15, and the first station was sampled only 12 hours out of port. Station 1 was a joint station with the R/V Hermano Gines from the EDIMAR Laboratory, Margarita, Venezuela, just outside the sill of the Cariaco Basin. Some joint nutrient samples were taken and analyzed aboard each ship. Then the Knorr began the Caribbean portion of the A22 transect, which ended with Station 23 on 300-m depth south of Puerto Rico on August 20, 1997. The Knorr jogged around the eastern end of the Island, and the transect was resumed north of Puerto Rico along approximately $66^{\circ} \mathrm{W}$ and continued until Station 77 in $200 \mathrm{~m}$ of water on the shelf south of Cape Cod, Massachusetts, on September 2, 1997. Some 77 WOCE hydrostations were occupied during this leg. In addition, 10 floats and 9 drifters were deployed and one mooring was recovered. All of the carbon parameter instruments, including the underway SOMMA, functioned satisfactorily until the end of the cruise; and fortunately a back-up coulometer was never needed. The R/V Knorr docked in Woods Hole

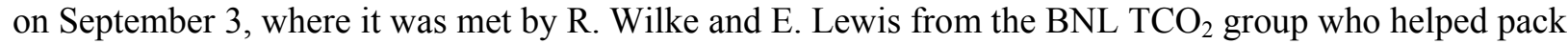
the equipment The entire $\mathrm{TCO}_{2}$ measurement group with its equipment departed Woods Hole on the afternoon of September 4, 1997. 


\section{DESCRIPTION OF MEASUREMENTS AND METHODS}

\subsection{Hydrographic Measurements}

During the cruises, the responsibility for the hydrographic data was divided between Scripps Institution of Oceanography (SIO) (section A24) and WHOI (sections AR24, A20, and A22). Hence the hydrography description is given in separate sections for SIO and WHOI operations and methods.

\subsubsection{SIO/Ocean Data Facility Methods and Instrumentation (Section A24)}

The SIO hydrographical procedures are described in detail by Lynne Talley in the chief scientist's cruise report for WOCE Section A24, which can be obtained on the WHPO web site at http://whpo.ucsd.edu/data/onetime/atlantic/a24/index.htm. Navigational data were logged automatically at 1-minute intervals on a Sun SPARC station. Underway bathymetry was acquired from the ship's SeaBeam system at 5-minute intervals. These data were merged with the navigation data to provide a time-series of underway position, course, speed, and bathymetry, which were used for all station positions, depths, and for bathymetry on vertical sections. A thermosalinograph (Falmouth Scientific Instruments) was mounted on the bow approximately $3 \mathrm{~m}$ below the surface for underway salinity.

The hydrographic casts were made with a 36-position 10-L rosette system belonging to the Ocean Data Facility (ODF) at SIO. This unit consisted of a 36-bottle frame, thirty-one 10-L Niskin bottles, a Neil Brown Instrument System (NBIS) Mark III CTD with dual conductivity and temperature sensors, transmissometer, LADCP, altimeter, and pinger. The rosette system was suspended from a threeconductor 0.322-inch electromechanical cable, and power to the CTD and pylon was provided through the cable from the ship. For the first 10 casts, a General Oceanics 1016 36-place pylon was used; thereafter a Sea Bird Electronics (SBE), 36-place pylon, and SBE 33 deck unit were used. The rosette was deployed from the starboard side hangar, and the port side Markey CTD winch was used throughout section A24. At the beginning of each station, the time, position, and bottom depth were logged; the sensors were powered; and control was transferred to the CTD acquisition and control system in the ship's laboratory and the CTD lowered to within $10 \mathrm{~m}$ of the bottom. The CTD provided real-time pressure, depth, temperature, salinity (conductivity), oxygen, and density, and these variables were used to select the sampling depths.

At the end of each cast, water samples (full suite) were drawn in the following order: chlorofluorocarbons (CFCs), helium, oxygen, $\mathrm{pCO}_{2}, \mathrm{TCO}_{2}, \mathrm{TALK}$, tritium, nutrients, and salinity. However, only salinity, oxygen, and nutrients were measured at every station. A log was kept to document the sampling sequence and to note anomalies (e.g., leaks), and WHP quality flags were assigned to each sample using the analyzed bottle salinities, oxygen, and nutrients. No major problems with the CTD operation were experienced, and the original set of 31 Niskin bottles was used throughout section A24. At the end of the cruise, the CTD and the entire acquisition and control system were packed and shipped back to SIO.

The CTD was calibrated for pressure and temperature at the ODF calibration facility (La Jolla, California) in April 1997, prior to WOCE section A24. At sea, bottle salinity and oxygen were used to calibrate the conductivity and oxygen sensors, respectively, and the temperature calibration was checked with an SBE 35 laboratory-grade reference material. Further details concerning the pre- and post-cruise calibration of the CTD sensors can be found in the cruise report available from WHPO. ADCP and LADCP profiles were made throughout the section using the hull-mounted ADCP system permanently installed on the Knorr and the LADCP mounted vertically inside the rosette frame bottle rings. The quality of the shipboard ADCP to depths of $500 \mathrm{~m}$ was good throughout the cruise, as were the LADCP station profiles.

Bottle salinity samples were collected after three rinses in 200-mL Kimax high alumina borosilicate bottles, sealed, and determined after thermal equilibration, usually within 8 to 12 hours of collection. 
Salinity was determined at $24^{\circ} \mathrm{C}$ on two Guildline Autosal Model $8400 \mathrm{~A}$ salinometers located in a temperature-controlled laboratory $\left(21.4-24.6^{\circ} \mathrm{C}\right)$. The salinometer was standardized with International Association for the Physical Sciences of the Ocean (IAPSO) standard seawater (SSW) batch P-127, using at least one fresh vial per cast. The accuracy of the determination was 0.002 relative to the SSW batch used. Salinity was then calculated for each sample (UNESCO 1981) and merged into the data base.

Bottle oxygen was determined by filling $125-\mathrm{mL}$ iodine flasks to overflowing ( $3 \times$ bottle volume) with a draw tube after two bottle rinses. Sample temperature was measured immediately with a thermometer imbedded in the draw tube. The Winkler reagents were added, the flasks stoppered, and shaken upon stoppering and shaken again 20 minutes later to ensure that the dissolved oxygen was completely fixed. Oxygen was determined according to the technique of Carpenter (1965), incorporating the modifications of Culberson et. al (1991) within 4 hours of collection on an SIO-designed automated oxygen titrator using photometric endpoint detection at an ultraviolet wave length of $365 \mathrm{~nm}$. Standards prepared from pre-weighed potassium iodate were run each time the automated titrator was used, and reagent blanks were determined by analyzing distilled water. The final oxygen results have been converted to $\mu \mathrm{mol} / \mathrm{kg}$. Conversion was done using the in-situ temperature, not the temperature of the sample from the Niskin bottles, because of a software failure. Bottle volumes were precalibrated at SIO. The precision of the analysis calculated from 57 replicate pairs (duplicates drawn from the same Niskin bottle) was \pm $0.004 \mathrm{~mL} / \mathrm{L}$.

Phosphate, nitrate, nitrite, and silicate were determined on virtually every Niskin bottle closed from stations 1 through 153 . The samples were collected in $45-\mathrm{mL}$ high-density polypropylene, narrow-mouth, screw-capped centrifuge tubes that were rinsed with HCL and then rinsed three times with sample before filling. The samples were analyzed on an ODF-modified four-channel Technicon AutoAnalyzer II, usually within 1 hour of the cast, in a temperature-controlled laboratory. If the samples were stored for longer than 1 hour prior to analysis, they were stored at $4{ }^{\circ} \mathrm{C}$ (no more than 4 hours). The Auto Analyzer instrumentation - which incorporates the method of Armstrong, Stearns, and Strickland (1967) for silicate, the method of Armstrong et al. (1967) as modified for nitrate and nitrite, and the method of Bernhardt and Wilhelms (1967) for phosphate-is described by Gordon and co-workers (Atlas et al. 1971; Hager et al. 1972; Gordon et al. 1992). Standards were analyzed at the beginning and end of each group of sample analyses with a set of secondary intermediate concentrations prepared by diluting preweighed primary standards. The primary standard for silicate was $\mathrm{Na}_{2} \mathrm{SiF}_{6}$; for nitrate, nitrite, and phosphate, $\mathrm{KNO}_{3}, \mathrm{NaNO}_{2}$, and $\mathrm{KH}_{2} \mathrm{PO}_{4}$ were used, respectively. Chemical purities ranged from $99.97 \%$ $\left(\mathrm{NaNO}_{3}\right)$ to $99.999 \%\left(\mathrm{KNO}_{3}\right)$. Deep seawater was also used as a substandard. Some 3439 nutrient samples were analyzed during section A24.

\subsubsection{WHOI Methods and Instrumentation (Sections AR24, A20, and A22)}

Unless otherwise stated, procedures remain as in Section 3.1.1. The underway-Doppler speed log did not function during sampling of section A22, and the hull-mounted transducer had to be removed for repair. Otherwise, navigational and meteorological data were logged by the shipboard data acquisition system (dubbed Athena) at 1-minute intervals. These data include heading, time and date, geographic positioning system (GPS), wind speed and direction, sea surface temperature and conductivity, and additional meteorological data. A secondary suite of data calculated or derived from these data was also logged at 1-minute intervals. These files were also the source of event-specific data (e.g., station location). Underway salinity was calibrated with bottle salinity.

For the WHOI sections, the Knorr was outfitted with equipment belonging to WHOI. For details see the chief scientist's report for Sections A20 and A22 on the WHPO web site:

http://whpo.ucsd.edu/data/onetime/atlantic/index.htm. The CTD used was a WHOI-modified NBIS MarkIII CTD with oxygen sensor, conductivity cell, LADCP, pressure transducer, temperature sensor, and pinger mounted on a 33-position 10-L Niskin bottle rosette frame. The AR24 section differed from the A20 and A22 sections and virtually all other $\mathrm{CO}_{2}$ survey work because a 24-bottle rosette was used with 4-L sampling bottles, instead of the usual 10-L Niskin bottles, in order to reduce sampling time at the 
rosette in late fall when seas were expected to be rougher. A General Oceanic-1016 pylon was used and was controlled using an SIO-furnished Surface Control Interface, a dedicated PC, and software provided by SIO/ODF. Temperature and pressure calibrations were performed at WHOI before section A20. The CTD was re-calibrated after its return to WHOI in December 1997. For details concerning the pre-cruise, at-sea, and post-cruise CTD calibrations, see the cruise report and Millard and Yang (1993).

Oxygen, nutrients, and salts were analyzed from virtually every Niskin bottle closed during the cruise. Bottle salinity samples were collected after two rinses in 8-ounce glass bottles. Then they were thermally equilibrated to $22^{\circ} \mathrm{C}$ and analyzed on a Guildline Autosal Model $8400 \mathrm{~B}$ salinometer. The salinometer was standardized once a day using IAPSO SSW Batch P-131 (dated October 10, 1996). The accuracy was \pm 0.002 .

Bottle oxygen was determined by filling $15-\mathrm{mL}$ brown glass tincture bottles. Oxygen was determined using a modified Winkler technique similar to that described by Strickland and Parsons (1972). The titration is automated using a PC controller and a Metrohm Model 665 Dosimat buret. The endpoint is determined amperometrically using a dual-plate platinum electrode, with a resolution of better than $0.001 \mathrm{~mL}$. The accuracy of the method is $0.02 \mathrm{~mL} / \mathrm{L}$ with a standard deviation of replicate samples of \pm 0.005 . Standardization of the thiosulphate titrant was done daily. No problems were noted during the cruises. This technique is described further by Knapp, Stalcup, and Stanley (1990).

The nutrient samples were collected in $30-\mathrm{mL}$ high-density polypropylene bottles that were loaded directly into the autosampler tray. The bottles were soaked in $10 \% \mathrm{HCl}$ every other day and rinsed three times with sample before filling. The samples were analyzed on the same SIO/ODF-modified fourchannel Technicon AutoAnalyzer II used on A24, except that an Alpkem Model 303 autosampler was substituted for the ODF autosampler. The analytical methods are described in Gordon et al. (1994).

\subsection{Total $\mathrm{CO}_{2}$ Measurements}

As on previous cruises, $\mathrm{TCO}_{2}$ was determined using automated dynamic headspace sample processors (SOMMA) with coulometric detection of the $\mathrm{CO}_{2}$ extracted from acidified samples. A description of the SOMMA-Coulometry System and its calibration can be found in Johnson et al. (1987), Johnson and Wallace (1992), and Johnson et al. (1993). A schematic diagram of the SOMMA analytical sequence may be found in earlier cruise reports (see Johnson et al. 1995,1996), and further details concerning the coulometric titration can be found in Huffman (1977) and Johnson, King, and Sieburth (1985). The methods used for discrete $\mathrm{TCO}_{2}$ on WOCE sections have been extensively dealt with in previous reports (Johnson et al. 1998a) and need only be briefly summarized.

The AR24 section required modification of the usual sampling procedures. As noted in Section 3.1.2, 4-L sampling bottles were employed on the rosette, limiting the amount of sample available for the carbonate system analysts to one $500-\mathrm{mL}$ bottle. Hence, the $\mathrm{TCO}_{2}$ coulometric titration analysis had to be completed before the partially empty $500-\mathrm{mL}$ bottle was passed to the TALK group for the potentiometric alkalinity titration. There was enough sample to complete both measurements, but not enough time or sample for $\mathrm{TCO}_{2}$ replicate analyses from the same $500-\mathrm{mL}$ sample bottle. The 4-L sampling bottles also made it impossible to draw duplicate samples from the same sampling bottle. Without duplicate samples from the hydrographic stations, standard measures of sample precision (DOE 1994; Johnson et al. 1998b) could not be completed on the AR24 section. Samples were poisoned with $100 \mu \mathrm{L}$ of a $50 \%$ solution of $\mathrm{HgCl}_{2}$ and analyzed for $\mathrm{TCO}_{2}$ within 24 hours of collection (DOE 1994).

For sections A24, A20, A22, single or duplicate samples were collected in 300-mL biological oxygen demand (BOD) bottles, poisoned with $100 \mu \mathrm{L}$ of a $50 \%$ solution of $\mathrm{HgCl}_{2}$, and analyzed for $\mathrm{TCO}_{2}$ within 24 hours of collection, according to standard operating procedures (DOE 1994). The samples were stored in a dark refrigerator at $4-6^{\circ} \mathrm{C}$ until approximately $1-2$ hours before analysis, when they were removed and placed in a temperature bath at $18-20^{\circ} \mathrm{C}$ and thermally equilibrated. The SOMMA sample pipette and sample bath were also kept at approximately $20^{\circ} \mathrm{C}$. Duplicate samples were usually collected on each cast at the surface and from the bottom waters. For some casts, three sets of duplicates were taken. The duplicates were analyzed within the run of cast samples from which they originated so that the time 
elapsed between duplicate analyses was 3-12 hours. As per standard operating procedure (DOE 1994), CRM was routinely analyzed according to DOE (1994) guidelines. The CRM was supplied by Dr. Andrew Dickson of the SIO, and for the North Atlantic cruises, batches 33, 36, and 37 were used. The certified values for these batches were $\mathrm{TCO}_{2}=2009.85 \mu \mathrm{mol} / \mathrm{kg} @$ salinity $=33.781$ for batch $33 ; \mathrm{TCO}_{2}$ $=2050.21 \mu \mathrm{mol} / \mathrm{kg} @$ salinity =35.368 for batch 36 ; and $\mathrm{TCO}_{2}=2044.15 \mu \mathrm{mol} / \mathrm{kg} @$ alinity $=34.983$ for batch 37 . The $\mathrm{CRM} \mathrm{TCO}_{2}$ concentration was determined by vacuum-extraction/manometry in the laboratory of C. D. Keeling at SIO.

An accurately known volume of seawater was injected from an automated to-deliver (TD) pipette into a stripping chamber. Following acidification, the resultant $\mathrm{CO}_{2}$ from continuous gas extraction was dried and coulometrically titrated on a model 5011 UIC coulometer with a maximum titration current of $50 \mathrm{~mA}$ in the counts mode (the number of pulses or counts generated by the coulometer's VFC during the titration was displayed). In the coulometer cell, the acid (hydroxyethylcarbamic acid) formed from the reaction of $\mathrm{CO}_{2}$ and ethanolamine is titrated coulometrically (electrolytic generation of $\mathrm{OH}^{-}$) with photometric endpoint detection. The product of the time and the current passed through the cell during the titration (charge in coulombs) is related by Faraday's constant to the number of moles of $\mathrm{OH}^{-}$generated and thus to the moles of $\mathrm{CO}_{2}$ that reacted with ethanolamine to form the acid. The age of each titration cell is logged from its birth (time that electrical current is applied to the cell) until its death (time when the current is turned off). The age is measured in minutes from birth (chronological age) and in mgC titrated since birth (carbon age).

Each system was controlled with an IBM-compatible PC equipped with two RS232 serial ports (coulometer and barometer), a 24-line digital input/output card (solid state relays and valves), and an analog-to-digital card (temperature, conductivity, and pressure sensors). Real Time Devices (located in State College, PA 16803) manufactured the cards. The SOMMA temperature sensors (model LM34CH, National Semiconductor, Santa Clara, CA) with a voltage output of $10 \mathrm{mV} /{ }^{\circ} \mathrm{F}$ were calibrated against thermistors certified to $0.02^{\circ} \mathrm{F}$ prior to the cruise using a certified mercury thermometer. These sensors monitored the temperature of SOMMA components, including the pipette, gas sample loops, and coulometer cell. The SOMMA software was written in GWBASIC Version 3.20 (Microsoft Corp., Redmond, WA), and the instruments were driven from an options menu appearing on the PC monitor. With the coulometers operated in the counts mode, conversions and calculations were made using the SOMMA software rather than the programs and the constants hardwired into the coulometer circuitry.

The SOMMA-coulometry systems were calibrated with pure $\mathrm{CO}_{2}$ (calibration gas) using hardware consisting of an 8-port gas sampling valve (GSV) with two sample loops of known volume [determined gravimetrically by the method of Wilke, Wallace, and Johnson (1993)] connected to the calibration gas through an isolation valve; the vent side of the GSV was plumbed to a barometer. When a gas loop was filled with $\mathrm{CO}_{2}$ at known temperature and pressure, the mass (moles) of $\mathrm{CO}_{2}$ contained therein was calculated, and the ratio of the calculated mass to that determined coulometrically was the calibration factor (CALFAC); the CALFAC was used to correct the subsequent sample titrations for small departures from $100 \%$ recoveries (DOE 1994). The standard operating procedure was to make gas calibrations daily for each newly prepared titration cell [normally, one cell per day and three sequential calibrations per cell at a carbon age of 3-9 mgC (mean age @ $6 \mathrm{mgC}$ ), with the result of the third calibration taken as the CALFAC if it was consistent with the second (i.e., agreement to $\pm 0.1 \%$ or better)]. Daily gas calibrations were made on both systems throughout the cruises.

The "to-deliver" volume $\left(\mathrm{V}_{\text {cal }}\right)$ of the sample pipettes was determined (calibrated) gravimetrically prior to the cruise to $\pm 0.02 \%$ or better in October of 1996 . The calibration was checked periodically during all cruises by collecting aliquots of deionized water dispensed from the pipette into pre-weighed serum bottles. The serum bottles were crimp-sealed and weighed immediately during the on-shore laboratory calibrations, or returned to shore where they were reweighed on a model R300S balance (Sartorius, Göttingen, Germany) as soon as possible. The apparent weight ( $\mathrm{g}$ ) of water collected ( $\mathrm{W}_{\text {air }}$ ) was corrected to the mass in vacuum $\left(\mathrm{M}_{\mathrm{vac}}\right)$ with the "to-deliver" volume being $\mathrm{M}_{\mathrm{vac}}$ divided by the density of the calibration fluid at the calibration temperature. After the AR24 section in 1996, the system pipettes were dismounted and replaced with chemically cleaned pipettes in March, 1997. For the 1997 
sections, the calibration volumes $\left(\mathrm{V}_{\text {cal }}\right)$ at the calibration temperature $\left(\mathrm{t}_{\mathrm{cal}}\right)$ of the sample pipettes were redetermined to $\pm 0.01 \%$ from a set of calibration samples taken on July 3, 1997, on board the Knorr at the completion of section A24 and were weighed on September 17. The $\mathrm{TCO}_{2}$ pipette volumes for the four North Atlantic sections are summarized in Table 2.

Table 2. The "to-deliver" pipette volume $\left(\mathrm{V}_{\text {cal }}\right)$ and calibration temperature $\left(t_{\text {cal }}\right)$ for the discrete SOMMA-Coulometer Systems (S/N 004 and 030) used on WOCE Section AR24 (1996) and Sections A24, A20, and A22 (1997)

\begin{tabular}{|l|c|c|c|}
\hline \multicolumn{1}{|c|}{ Section } & System $\mathbf{~} / \mathbf{N}$ & $\mathbf{V}_{\text {cal }}(\mathbf{m L})$ & $\mathbf{t}_{\text {cal }}\left({ }^{\circ} \mathbf{C}\right)$ \\
\hline AR24 (1996) & 004 & 21.8927 & 19.91 \\
\hline A24/A20/A22 (1997) & 004 & 21.2630 & 19.19 \\
\hline AR24 (1996) & 030 & 21.3733 & 20.91 \\
\hline A24/A20/A22 (1997) & 030 & 25.8544 & 19.52 \\
\hline
\end{tabular}

The sample volume $\left(V_{t}\right)$ at the pipette temperature was calculated from the expression:

$$
V_{t}=V_{c a l}\left[1+a_{v}\left(t-t_{\mathrm{cal}}\right)\right]
$$

where $a_{v}$ is the coefficient of volumetric expansion for pyrex-type glass $\left(1 \times 10^{-5} /{ }^{\circ} \mathrm{C}\right)$, and $t$ is the temperature of the pipette at the time of a measurement. The mean pipette temperature on the AR24 section in 1996 was $20.32 \pm 0.51^{\circ} \mathrm{C}(\mathrm{n}=948)$, and on the 1997 North Atlantic Sections it was $19.55 \pm 0.52^{\circ} \mathrm{C}(\mathrm{n}=4666)$.

The factory-calibrated coulometers were electronically calibrated independently in the laboratory before the cruise as described in Johnson et al. $(1993,1996)$ and DOE $(1994)$, and the terms $I N T_{\mathrm{ec}}$ and $S L O P E_{\text {ec }}$ were obtained and entered into the software for each system. The micromoles of carbon titrated (M), whether extracted from water samples or the gas loops, was

$$
M=\left[\text { Counts } / 4824.45-\left(\text { Blank } \times T_{\mathrm{t}}\right)-\left(I N T_{\mathrm{ec}} \times T_{\mathrm{i}}\right)\right] / S L O P E_{\mathrm{ec}}
$$

where 4824.45 (counts/ $\mu \mathrm{mol}$ ) is a scaling factor obtained from the factory calibration; $T_{\mathrm{t}}$ is the length of the titration in minutes; Blank is the system blank in $\mu \mathrm{mol} / \mathrm{min} ; I N T_{\mathrm{ec}}$ is the intercept from electronic calibration in $\mu \mathrm{mol} / \mathrm{min} ; T_{\mathrm{i}}$ is the time in minutes during the titration where current flow was continuous; and $S L O P E_{\text {ec }}$ is the slope from electronic calibration. Note that the slope obtained from the electronic calibration procedure applied for the entire length of the titration, but the intercept correction applied only for the period of continuous current flow (usually 3-4 min) because the intercept can be calculated only from calibrated levels of current flowing continuously.

Unfortunately, the coulometer system 030 , which was electronically calibrated prior to the AR24 cruise and again in March 1997, had to be replaced at the start of section A24 in May 1997. However, the replacement coulometer (S/N CBE-9010-V) was calibrated at the factory on March 20, 1997. Hence we assumed that the replacement coulometer was properly calibrated, and we entered the default calibration coefficients into the software $\left(S L O P E_{\mathrm{ec}}=1.0\right.$ and $\left.I N T_{\mathrm{ec}}=0.0\right)$. The system 004 was also recalibrated in March 1997 following the AR24 cruise with nearly identical results to those obtained in October 1996, and it was not recalibrated during the 1997 WOCE sections. The electronic calibration coefficients, along with the mean gas calibration factors determined for the North Atlantic section discrete $\mathrm{TCO}_{2}$ coulometers, are given in Table 3.

Table 3 illustrates an advantage of the independent laboratory electronic calibration procedure. The mean CALFAC for systems 004 and 030 using the laboratory-determined electronic calibration coefficients was approximately 1.0036 (or $99.64 \%$ recovery of the theoretical mass of $\mathrm{CO}_{2}$ calibration gas measured coulometrically) vs 1.0053 (99.47\% recovery) for the factory-calibrated coulometer. Hence, a small percentage $(0.17 \%)$ of the less than $100 \%$ recovery for known masses of $\mathrm{CO}_{2}$ coulometrically 
Table 3. The electronic calibration and the mean gas calibration coefficients for the discrete $\mathrm{TCO}_{2} \mathrm{systems}$ on WOCE Section AR24 (1996) and Sections A24, A20, and A22 (1997)

\begin{tabular}{|l|c|c|c|c|c|c|}
\hline \multicolumn{1}{|c|}{ Section } & System S/N & $\boldsymbol{S L O P E}_{\text {ec }}$ & $\begin{array}{c}\boldsymbol{I} \boldsymbol{N} \boldsymbol{T}_{\text {ec }} \\
\boldsymbol{\mu m o l} / \mathbf{m i n}\end{array}$ & CALFAC(n) & St. dev. & $\begin{array}{c}\text { Rel. st. dev. } \\
(\mathbf{\%})\end{array}$ \\
\hline AR24 & 004 & 0.999372 & 0.002528 & $1.003892(9)$ & 0.000650 & 0.06 \\
\hline A20/A22/A24 & 004 & 0.998905 & 0.001466 & $1.003361(63)$ & 0.000740 & 0.07 \\
\hline AR24 & 030 & 0.999306 & 0.003550 & $1.003780(26)$ & 0.000497 & 0.05 \\
\hline A20/A22/A24 & $030^{a}$ & 1.000000 & 0.000000 & $1.005344(59)$ & 0.001369 & 0.13 \\
\hline
\end{tabular}

${ }^{a}$ Factory-calibrated coulometer installed at the beginning of the A24 section in May 1997.

titrated can be explained by a factory-calibration procedure that is apparently slightly less accurate than the laboratory calibration. This difference has been consistent throughout the $\mathrm{CO}_{2}$ survey.

For water samples, the discrete $\mathrm{TCO}_{2}$ concentration in $\mu \mathrm{mol} / \mathrm{kg}$ was calculated from

$$
\mathrm{TCO}_{2}=M \times C A L F A C \times\left[1 /\left(V_{t} \times \rho\right)\right] \times d_{H g}
$$

where $\rho$ is the density of sea water in $\mathrm{g} / \mathrm{mL}$ at the measurement temperature and sample salinity calculated from the equation of state given by Millero and Poisson (1981), and $d_{H g}$ is the correction for sample dilution with bichloride solution (for the AR24 section in $1996 \mathrm{dHg}=1.0002$ and for the 1997 sections $d_{H g}=1.000333$ ).

One of the SOMMA-Coulometry Systems (S/N 004) was equipped with a conductance cell (Model SBE-4, Sea-Bird Electronics, Inc., Bellevue, WA) for the determination of salinity measurement as described by Johnson et al. (1993). Whenever possible SOMMA and CTD salinity were compared to identify mistrips or other anomalies, but the bottle salinity (furnished by the chief scientist) was used to calculate $\mathrm{TCO}_{2}$.

Quality control-quality assurance (QC-QA) was assessed from the results of the 275 CRM analyses made using systems 004 and 030 during the four North Atlantic sections. These data are summarized in Table 4, and the temporal distribution of the differences is plotted in Fig. 2 for section AR24 (1996) and in Fig. 3 for sections A24, A20, and A24 (1997).

Table 4. The mean analytical difference $\left(\Delta \mathrm{TCO} \mathrm{O}_{2}=\right.$ measured-certified $)$ and the standard deviation of the differences between measured and certified $\mathrm{TCO}_{2}$ on WOCE Sections AR24, A24, A20, and A22

\begin{tabular}{|l|c|c|c|c|}
\hline \multicolumn{1}{|c|}{ Section } & System S/N & $\begin{array}{c}\Delta \text { TCO } \\
(\boldsymbol{\mu m o l} / \mathbf{k g})\end{array}$ & $\begin{array}{c}\text { St. dev. } \\
(\boldsymbol{\mu m o l} / \mathbf{k g})\end{array}$ & $\mathbf{n}$ \\
\hline AR24 & 004 & 1.42 & 2.10 & 16 \\
\hline AR24 & 030 & 1.54 & 1.88 & 49 \\
\hline Mean/total & & $\mathbf{1 . 5 1}$ & $\mathbf{1 . 9 2}$ & $\mathbf{6 5}$ \\
\hline A24 & 004 & 0.04 & 1.10 & 49 \\
\hline A20 & 004 & 0.23 & 1.20 & 42 \\
\hline A22 & 004 & 0.06 & 0.69 & 17 \\
\hline Mean/total & & $\mathbf{0 . 1 0}$ & $\mathbf{1 . 0 8}$ & $\mathbf{1 0 8}$ \\
\hline A24 & 030 & 0.79 & 1.00 & 48 \\
\hline A20 & 030 & 0.44 & 1.43 & 35 \\
\hline A22 & 030 & 0.26 & 1.22 & 19 \\
\hline Mean/total & & $\mathbf{0 . 5 7}$ & $\mathbf{1 . 2 1}$ & $\mathbf{1 0 2}$ \\
\hline Overall mean/total & & $\mathbf{0 . 6 1}$ & $\mathbf{1 . 4 7}$ & $\mathbf{2 7 5}$ \\
\hline
\end{tabular}


Knorr, WOCE AR24

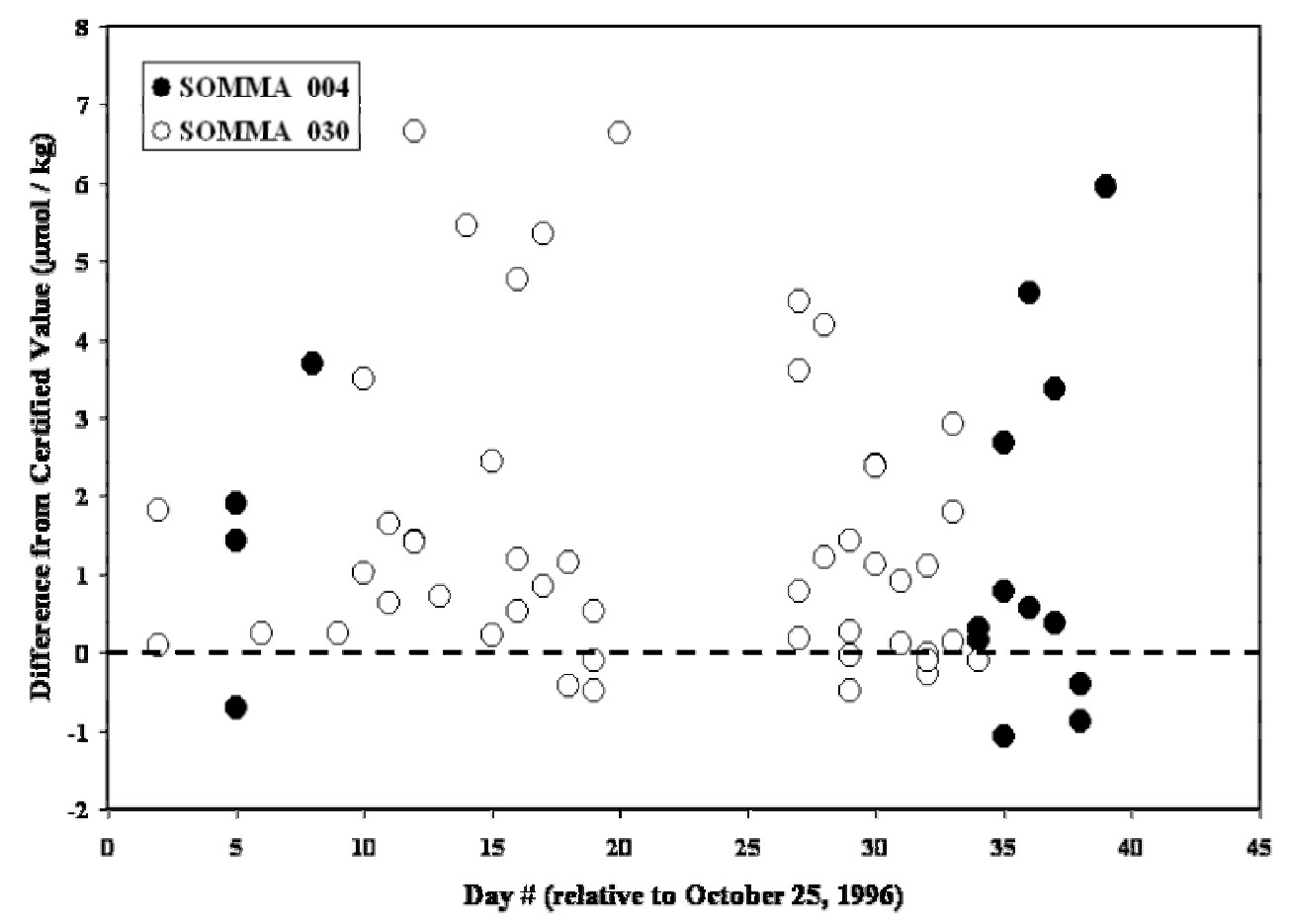

Fig. 2. The temporal distribution of differences between the measured and certified $\mathrm{TCO}_{2}$ for CRM analyzed on SOMMA-coulometry systems 004 (closed circles) and 030 (open circles) during the WOCE North Atlantic Section AR24 in 1996. The differences were calculated by subtracting the certified $\mathrm{TCO}_{2}$ from the measured $\mathrm{TCO}_{2}$.

The overall accuracy of the CRM analyses was better than $1 \mu \mathrm{mol} / \mathrm{kg}$ on both systems for the four North Atlantic sections, with a combined overall mean difference of $+0.61 \mu \mathrm{mol} / \mathrm{kg}(\mathrm{n}=275)$. However, Table 4 shows that on the AR24 section (1996), the mean difference and the standard deviation of the differences were noticeably larger for both systems compared with the 1997 sections (A24/A20/A22). This may be due in part to mechanical problems experienced by the AR24 measurement group, operator procedures, and possibly the relatively short time available to service and re-calibrate the systems prior to the AR24 section. The latter was brought about by the fact that system 004 had been used in the Indian Ocean from 1994-1996 and was only returned to BNL for service, repair, and re-calibration in the fall of 1996. System 030, which was a newly built system returned to the laboratory after a test cruise in the North Atlantic, also was not returned until the summer of 1996. For the 1997 sections, both systems were available in the laboratory for servicing from January through May of 1997. Indeed, the 1997 WOCE sections represented the only opportunity during the $\mathrm{CO}_{2}$ survey for the BNL measurement group to thoroughly service and test the systems, reagents, and analytical gases in the laboratory with real samples and CRM prior to shipment. As a result, the accuracy and precision of the CRM analyses made in 1997 (see Table 4) probably represent the highest quality possible for these systems under field conditions.

All CRM analyses made on the discrete systems (004 and 030) during the 1997 sections are reported in Table 4. However, for section AR24, two CRM analyses were classified as outliers and dropped from the data set. These were CRM No. 206 run on system 030 on November 23 (difference $=$ $+10.17 \mu \mathrm{mol} / \mathrm{kg}$ ) at a cell carbon age of $39.5 \mathrm{mgC}$, and CRM No. 600 on system 030 on November 
Knorr, WOCE A24, A20, and A22

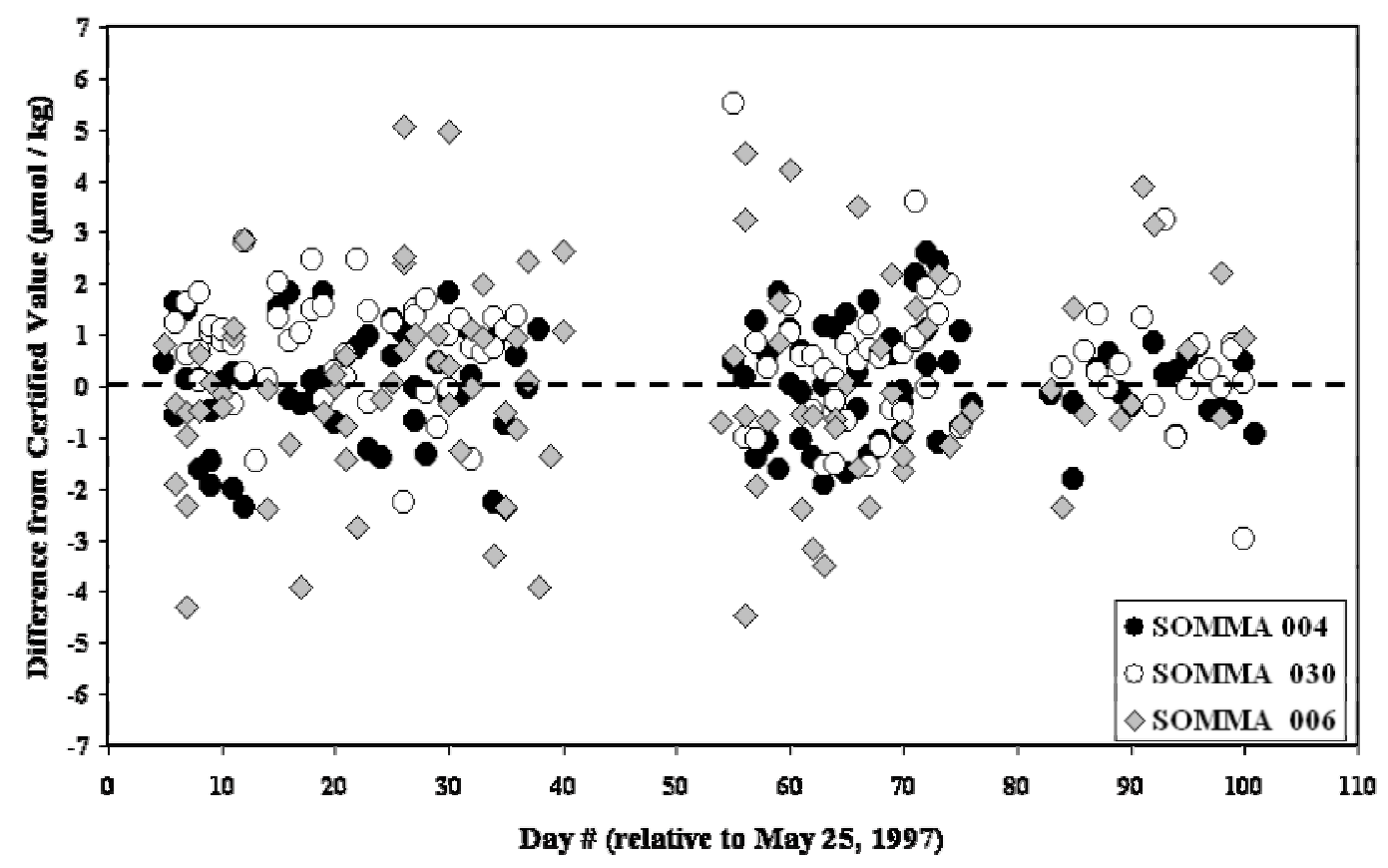

Fig. 3. The temporal distribution of differences among the measured and certified $\mathrm{TCO}_{2}$ for CRM analyzed on SOMMA-coulometry systems 004 (closed circles) and 030 (open circles) and 006 (shaded diamonds) during the WOCE North Atlantic Sections A24, A20, and A22 in 1997. The differences were calculated by subtracting the certified $\mathrm{TCO}_{2}$ from the measured $\mathrm{TCO}_{2}$.

28 (difference $=+7.99 \mu \mathrm{mol} / \mathrm{kg}$ ) at a carbon age of $35.7 \mathrm{mgC}$. One CRM analysis (CRM No. 352) run on system 004 on December 1 is not included in the data set because the titration did not attain an endpoint.

The second phase of the QC-QA procedure was an assessment of precision. As described in the text, duplicate samples could not be taken during the AR24 section in 1996. Hence the only estimate of AR24 sample precision was the standard deviation of the differences between the measured and certified $\mathrm{TCO}_{2}$ on both systems (see Table 4). Because differences from both systems have been combined, the CRM measurements are analogous to the sample duplicates analyzed on each system and should reflect both random and systemic error (bias). The decrease in precision for the CRM analyzed on the AR24 section in $1996( \pm 1.92 \mu \mathrm{mol} / \mathrm{kg})$ compared with the CRM analyzed in $1997( \pm 1.20 \mu \mathrm{mol} / \mathrm{kg})$ was consistent with the problems described for the 1996 leg. The good agreement in $\mathrm{TCO}_{2}$ between systems in 1996 (see Table 4) suggests that analyzing duplicate seawater samples on each system, as was done in 1997, might have yielded a higher precision than the precision of the CRM differences. Nevertheless, without sample duplicates, the AR24 sample precision must be based on the CRM analyses. Hence the precision of the $\mathrm{TCO}_{2}$ determination for the AR24 section in 1996 was $\pm 1.92 \mu \mathrm{mol} / \mathrm{kg}(\mathrm{n}=65)$. Because procedures and performance varied from 1996 to 1997, separate estimates of sample precision were required for each year; the data for 1997 are given in Table 5.

By 1997 the deployment of two independent SOMMA systems side-by-side was routine, and the conventions employed for the estimation of precision in the earlier WOCE data reports are retained in Table 5. For sections A24, A20, and A22 in 1997, the single-system precision was determined from samples with duplicates analyzed on the same system (either 004 or 030). The sample precision was calculated using duplicates that were analyzed on both systems (004 and 030). 
Table 5. Precision of the discrete $\mathrm{TCO}_{2}$ analyses on WOCE Sections A24, A20, and A22

\begin{tabular}{|c|c|c|c|c|c|c|c|}
\hline \multirow[b]{2}{*}{ Section } & \multicolumn{3}{|c|}{ Mean absolute difference } & \multicolumn{4}{|c|}{ Pooled standard deviation } \\
\hline & $\begin{array}{c}\sigma_{\mathrm{bs}} \\
(\mu \mathrm{mol} / \mathrm{kg})\end{array}$ & \pm St. dev. & $\mathbf{K}$ & $\begin{array}{c}\mathrm{S}_{\mathrm{p}}{ }^{2} \\
(\mu \mathrm{mol} / \mathrm{kg})\end{array}$ & $\mathbf{K}$ & $\mathbf{n}$ & d.f. \\
\hline \multicolumn{8}{|c|}{ Single-system precision } \\
\hline A24 & 1.08 & 1.01 & 175 & 1.04 & 175 & 350 & 175 \\
\hline A20 & 0.95 & 1.14 & 84 & 1.04 & 84 & 168 & 84 \\
\hline A22 & 0.99 & 0.93 & 71 & 0.96 & 71 & 142 & 71 \\
\hline \multicolumn{8}{|c|}{ Sample precision } \\
\hline All & 1.76 & 1.41 & 56 & 1.59 & 61 & 122 & 61 \\
\hline
\end{tabular}

Single-system and sample precision have been separately assessed in Table 5 as

- "between-sample" precision $\left(\sigma_{\mathrm{bs}}\right)$, which is the mean absolute difference between duplicates $(\mathrm{n}=2)$ drawn from the same Niskin bottle; and

- the pooled standard deviation $\left(\mathrm{S}_{\mathrm{p}}^{2}\right)$ calculated according to Youden (1951), where $K$ was the number of samples with duplicates analyzed, $n$ was the total number of replicates analyzed from $K$ samples, and $n-K$ was the degrees of freedom (d.f.).

Single-system precision provided a measure of drift in system response during a sequence of sample analyses. This is because the time lapse between duplicate analyses on the same system using the same coulometer cell was deliberately kept at 3-12 hours, on the assumption that drift or change in response would be reflected in the single-system precision by an increase in the imprecision of the duplicate analyses. Sample precision, on the other hand, was measured because $\mathrm{TCO}_{2}$ measurements were made on two separate systems, and an estimate of overall sample precision for the section (s), independent of which analytical system was used, was required. Sample precision is the most conservative estimate of precision, incorporating several sources of random or systematic (bias) error.

As on other sections in the Atlantic Ocean (e.g., A8 and A10) where SOMMA-coulometer systems have been run in parallel, the sample precision was slightly less than the single-system precision. This indicated that changes in system response during the coulometer cell lifetime in 1997 were clearly within the precision of the method $( \pm 1.59 \mu \mathrm{mol} / \mathrm{kg})$, while the slight but consistent decrease in sample precision compared with single-system precision was probably due at least in part to a small bias between the 004 and 030 systems. Although the precision was equivalent for both systems, system 030 gave on average slightly higher results than system 004 . For example, the mean $\Delta \mathrm{TCO}_{2}$ for system $004 \mathrm{CRM}$ was $+0.10 \mu \mathrm{mol} / \mathrm{kg}$, but it was $+0.57 \mu \mathrm{mol} / \mathrm{kg}$ for system $030 \mathrm{CRM}$ (see Table 4 ); while the mean of the seawater samples $(\mathrm{n}=56$, Table 5) analyzed on $030 \mathrm{was}+1.17 \mu \mathrm{mol} / \mathrm{kg}$ higher than the mean for the same samples analyzed on system 004. Hence the uniformly excellent single-system precision for 1997 cannot be used for sample precision, and analyzing duplicate replicates on each system remains the definitive measure of the overall precision of the 1997 data set and the $\mathrm{TCO}_{2}$ calibration procedures. The two discrete systems should give the same result for the same sample, and the extent to which they differ is a measure of the overall precision of the data set obtained with two independent systems. For $\mathrm{TCO}_{2}$ on the 1997 North Atlantic WOCE sections, the precision of the $\mathrm{TCO}_{2}$ determination was $\pm 1.59 \mu \mathrm{mol} / \mathrm{kg}$ $(\mathrm{K}=56)$.

The North Atlantic sample precision for all four sections in 1996 and $1997( \pm 1.92$ and $\pm 1.59 \mu \mathrm{mol} / \mathrm{kg}$, respectively) is in good agreement with the published and unpublished sample precision for other WOCE sections where systems were run in parallel: AE1, $1991( \pm 1.65 \mu \mathrm{mol} / \mathrm{kg}) ; \mathrm{P} 6,1992( \pm 1.65 \mu \mathrm{mol} / \mathrm{kg})$; A10, $1993( \pm 1.92 \mu \mathrm{mol} / \mathrm{kg}) ; A 8,1994( \pm 1.17 \mu \mathrm{mol} / \mathrm{kg}) ;$ Indian Ocean, $1995( \pm 1.20 \mu \mathrm{mol} / \mathrm{kg})$. During the 1997 North Atlantic sections, a limited number of duplicate samples $(K=6)$ were analyzed from two different Niskin bottles closed at the same depth, and the mean absolute difference and standard deviation was $0.77 \pm 0.50 \mu \mathrm{mol} / \mathrm{kg}$, which was consistent with earlier findings (e.g., Johnson et al. 1998a; Johnson 
et al. 2001) that there were likely no significant analytical effects due to gas exchange with the overlying headspace of the Niskin bottles during sampling.

Tables 4 and 5 show an internally consistent data set of high quality with excellent accuracy $(\leq 2.0 \mu \mathrm{mol} / \mathrm{kg})$, high single-system precision $(\leq \pm 1.0 \mu \mathrm{mol} / \mathrm{kg})$, and a slightly higher imprecision for the sample precisions $( \pm 1.59-1.92 \mu \mathrm{mol} / \mathrm{kg})$. Based on these data, the $\mathrm{TCO}_{2}$ data clearly meet survey criteria for accuracy $(\leq 4.0 \mu \mathrm{mol} / \mathrm{kg})$ and precision, and as with previous data submissions, no correction for instrumental bias or CRM analytical differences has been applied to the $\mathrm{TCO}_{2}$ data.

\subsection{Total Alkalinity Measurements}

TALK and $\mathrm{pH}$ were measured using an automated potentiometric titration system developed at the University of Miami (hereafter designated as MATS). MATS is described by Millero et al. (1993a). It consisted of two parts: a Metrohm model 665 Dosimat titrator and a pH meter (Orion, Model 720A) which are interfaced with a PC. A water-jacketed, fixed-volume $(\sim 200 \mathrm{~mL})$, closed Plexiglass sample cell, of greater volume than but otherwise similar to those used by Bradshaw and Brewer (1988), was used to increase the precision of the measurements. The cell, titrant burette, and sample cell were theromstatted at $25 \pm 0.05^{\circ} \mathrm{C}$ using a constant temperature bath (Neslab, Model RTE 221). A Lab Windows/CVI program was used to run the titrators, record the volume of titrant added, and record the measured electromagnetic frequency (emf) of the electrodes through RS232 serial interfaces. The electrodes for measuring the emf during the titration consisted of a ROSS glass $\mathrm{pH}$ electrode (Orion, Model 810100) and a double-junction $\mathrm{Ag} / \mathrm{AgCl}$ reference electrode (Orion, Model 900200).

Seawater samples were titrated by adding enough $\mathrm{HCl}$ to exceed the carbonic acid endpoint of the titration. During a typical titration, the emf readings were recorded until stable $( \pm 0.05 \mathrm{mV})$. Normally, at this point, a fixed volume of acid would be added; however, the MATS were designed to add enough acid to increase the voltage by a pre-assigned increment $(13 \mathrm{mV})$. This was done to give an even distribution of data points over the course of a full titration, which consists of 25 data points and takes about 20 minutes. With two systems, approximately 7 hours was required to run a 31-bottle station cast. As noted in Sections 3.1 and 3.2, 4-L Niskin sampling bottles were employed on the rosette, which limited the amount of sample available for the carbonate system analysts to one 500-mL bottle. Hence there was not enough sample water to complete duplicate alkalinity analyses from the same bottle or to draw duplicate samples from the same sampling bottle.

The titrant (acid) used throughout the cruises was prepared, standardized, and stored in 500-mL borosilicate glass bottles for use in the field. A single 55-gal batch of $0.25-\mathrm{m} \mathrm{HCl}$ acid was prepared by dilution of concentrated $\mathrm{HCl}$ (AR Select Mallinckrodt). The acid was prepared in $0.45-\mathrm{m} \mathrm{NaCl}$ to yield a total ionic strength similar to that of seawater salinity $35.0(\mathrm{I}=\sim 0.7 \mathrm{M})$. The acid was standardized by coulometry (Taylor and Smith 1959; Marinenko and Taylor 1968). The acid molality was also checked by titration on seawaters with known alkalinities, and subsamples were sent to the laboratory of A. Dickson at SIO for an independent laboratory determination of the molality. The calibrated molality of the acid used for the North Atlantic WOCE Sections was $0.24892 \pm 0.00003 \mathrm{~m} \mathrm{HCl}$.

The consistency of the method was checked for each cast using low-nutrient surface seawater, and the accuracy of the method was checked by analyzing CRM Batches 33 (1996), 36, and 37 (1997) and comparing the analyzed values with the certified TALK in the same manner as for $\mathrm{TCO}_{2}$ (see also Section 3.2 for batch data). The mean differences between at-sea measurements and the certified TALK values are given in Table 6 . The TALK of each batch was also determined in the laboratory by weight titrations, which were found to agree with the certified values to $\pm 2 \mu \mathrm{mol} / \mathrm{kg}$. In addition, the $\mathrm{pH}$ of the CRM batches was determined in the laboratory spectrophotometrically according to the methods of Clayton and Byrne (1993) prior to the cruise. The at-sea titration $\mathrm{pH}$ measurements were also compared with the pre-cruise spectrophotometric values, and the reader is referred to Millero et al. (1999) for further details. 
Table 6. The mean analytical difference between analyzed and certified TALK for the MATS on WOCE Section AR24 (1996), and Sections A24, A20, and A22 (1997)

\begin{tabular}{|l|c|c|c|c|c|}
\hline Section & Cells & $\mathbf{n}$ & $\begin{array}{c}\text { CRM TALK } \\
\boldsymbol{\mu m o l} / \mathbf{k g}\end{array}$ & $\begin{array}{c}\text { Measured TALK } \\
\boldsymbol{\mu m o l} / \mathbf{k g}\end{array}$ & $\begin{array}{c}\Delta \text { TALK } \\
\boldsymbol{\mu m o l} / \mathbf{k g}\end{array}$ \\
\hline AR24 & $2,19,17$ & 59 & 2234.9 & 2233.3 & -1.6 \\
\hline A24 & $2,18,12$ & 148 & 2283.9 & 2283.3 & -0.6 \\
\hline A20 & $2,18,12$ & 96 & 2314.1 & 2217.1 & 3.0 \\
\hline A22 & 2,12 & 65 & 2314.1 & 2215.4 & 1.3 \\
\hline
\end{tabular}

The mean differences between the at-sea measurements and the certified TALK were within $3.0 \mu \mathrm{mol} / \mathrm{kg}$ (Table 6). Hence the measured and certified TALK were in good agreement. For $\mathrm{pH}$ and $\mathrm{TCO}_{2}$, the corresponding results were 0.021 and $9 \mu \mathrm{mol} / \mathrm{kg}$, respectively, with the larger deviation in $\mathrm{pH}$ attributable to the non-Nernstian behavior of the electrodes near a pH of 8 (Millero et al. 1993b).

The at-sea sample alkalinity titrations were corrected using the results for the CRM. For TALK, the CALFAC used to correct the at sea measurements was

$$
C A L F A C=C R M(\text { certified value }) /(\text { at-sea value })
$$

and for $\mathrm{pH}$ the CALFAC was

$$
p H=p H(\mathrm{CRM}) / \mathrm{pH}(\text { at-sea }) .
$$

Duplicate samples were usually taken for each station in the same manner as for $\mathrm{TCO}_{2}$ (surface and deep) and analyzed to determine and monitor the precision of the MATS. The average difference between replicates was $\pm 1.0, \pm 1.1$, and $\pm 1.1 \mu \mathrm{mol} / \mathrm{kg}$ for sections $\mathrm{A} 24, \mathrm{~A} 20$, and $\mathrm{A} 22$, respectively, which demonstrated the high precision of the MATS throughout the study. A preliminary description of the major trends in the data and the behavior of alkalinity over time in the North Atlantic is given by Millero et al. (1999).

\subsection{Discrete $\mathrm{pCO}_{2}$ Measurements}

The discrete measurements of $\mathrm{pCO}_{2}$ were performed by the LDEO group on three of four sections of the North Atlantic survey. During the WOCE sections A24, A20, and A22, a total of 2,465 samples were analyzed onboard the R/V Knorr (1,103, 595, and 767 samples respectively). On the earlier WOCE section $\mathrm{AR} 24$, discrete $\mathrm{pCO}_{2}$ was not measured.

An automated equilibrator-IR gas analyzer system was used during the expedition for the determination of partial pressure of $\mathrm{CO}_{2}$ in the seawater samples. Its design is similar to that described by Chipman, Marra, and Takahashi (1993) with the exception that the gas chromatograph was replaced with an IR gas analyzer. The equilibrator-IR system is shown schematically in Fig. 4.

The system consists of a circulation pump plumbed to recirculate air in a closed system through porous plastic gas dispersers immersed in a $250-\mathrm{mL}$ seawater sample. The seawater sample is contained in a 250-mL Pyrex reagent bottle with a standard taper-ground glass stopper that serves as an equilibration vessel. A Pyrex extension tube $(\sim 20 \mathrm{~mL})$, which has a standard taper-ground glass malejoint to form an airtight seal with the reagent bottle, is connected to the mouth of the reagent bottle to provide an extra headspace to prevent seawater from entering the gas circulation line. Four sets of flasks and circulation pumps are used so that four water samples can be processed concurrently. Because the partial pressure of $\mathrm{CO}_{2}$ is sensitive to temperature, the equilibration flasks are kept immersed in a water bath maintained at $20^{\circ} \mathrm{C}$. The temperature at which the water sample is equilibrated with circulating gas is measured with a precision of $\pm 0.01^{\circ} \mathrm{C}$ and is recorded. 
An electrically driven Valco 10-port valve (the equilibrator selection valve in Fig. 4) is used to isolate each of the equilibrators during the initial equilibration. Manually operated 2-way and 3-way Whitey valves allow the headspace in each equilibrator to be filled with a calibration gas of known $\mathrm{CO}_{2}$ concentration, creating a known initial condition for the headspace (about $40 \mathrm{~mL}$ ) before equilibration. The equilibrator is open to the laboratory air through isolation coils attached to the low-pressure side of the equilibrator, keeping the total pressure of equilibration the same as the ambient atmospheric pressure. The atmospheric pressure is measured with a high-precision electronic barometer with an accuracy of better than $0.05 \%$ and is recorded. It takes about 20 minutes for each water sample to be thermally equilibrated with the constant-temperature water bath, and the headspace gas is recirculated through the water sample throughout the period to ensure $\mathrm{CO}_{2}$ equilibration.

An electrically driven Valco 6-port valve (the sample selection valve in Fig. 4) is connected to the equilibrator selection valve and to the calibration gas selection valve. This allows selection of the gas sample to be analyzed for $\mathrm{CO}_{2}$ : the equilibrated sample gas or one of the four calibration gases. A 2-way normally-closed Skinner solenoid valve on the output of the calibration gas selection valve controls the flow of the calibration gases to the sample selection valve. It also provides a necessary second means of stopping the flow of the calibration gases to prevent their accidental loss in case of a control malfunction. The concentration of $\mathrm{CO}_{2}$ in the gas equilibrated with the seawater sample is determined using an IR gas analyzer (LICOR Model 6125) in a flow-through mode. A $0.5-\mathrm{mL}$ aliquot of equilibrated headspace gas, representing less than $1 \%$ of the circulating gas, is isolated using a gas pipette (attached to the sampling valve in Fig. 4) and swept with $\mathrm{CO}_{2}$-free air (or pure nitrogen gas) flowing at a constant rate of about $50 \mathrm{~mL} / \mathrm{min}$. For low-pCO ${ }_{2}$ samples, a $1-\mathrm{mL}$ gas pipette (attached to the sampling valve) is used. The sample gas is passed through a permeation drying tube for the removal of water vapor and injected into the IR gas analyzer cell (about $7 \mathrm{~mL}$ in volume) filled previously with $\mathrm{CO}_{2}$-free air. The displaced $\mathrm{CO}_{2}$ free air is discharged out of the cell into the laboratory. The small volume of the gas sample ensures that all of the $\mathrm{CO}_{2}$ from the gas pipette is found in the analyzer cell at the same time, so that the peak height is proportional to the amount of $\mathrm{CO}_{2}$ present in the gas pipette. Drying of the sample gas avoids the effects of pressure-broadening of the $\mathrm{CO}_{2}$ absorption spectra and of dilution caused by water vapor. The amount of $\mathrm{CO}_{2}$ in the sampling pipette is a function of the loop volume, temperature, and pressure. The temperature is held constant and measured, and the pressure of the sample gas is same as the barometric pressure, which is measured with an accuracy of better than $0.05 \%$. The peak height, which represents the number of moles of $\mathrm{CO}_{2}$ in the sample gas, is calibrated every 1.5 hours using a quadratic equation fitted to three calibration gas mixtures (366.52, 788.8 and $1211.4 \mathrm{ppm}$ mole fraction in dry air).

The analytical procedure begins with water samples being drawn from the 10-L Niskin bottles off a rosette directly into 250-mL Pyrex reagent bottles. These served as both sample containers and equilibration vessels. The samples were immediately inoculated with $100 \mu \mathrm{L}$ of $50 \%$ saturated mercuric chloride solution, sealed airtight with ground glass stoppers to prevent biological modification of the $\mathrm{pCO}_{2}$, and stored in the dark until analysis. Measurements were normally performed within 24 hours of sampling. A headspace of 3 to $5 \mathrm{~mL}$ was left above the water to allow for thermal expansion during storage. Prior to analysis, the sample flasks were brought to the water bath temperature of $20^{\circ} \mathrm{C}$ in the constant-temperature bath. The equilibrator headspace, including the extension tube and the gas circulation tubings, was filled with a calibration gas of known $\mathrm{CO}_{2}$ concentration. The gas in the equilibrators, and in the tubing that connects them to the gas pipette loop, was recirculated continuously for about 20 minutes through a gas disperser immersed in the water. This provided a large surface area for gas exchange between the sample water and circulating gas, and equilibrium for $\mathrm{CO}_{2}$ was attained in $15 \mathrm{~min}$. The temperature of the bath water was assumed to be that of the sample water and was measured at the time of equilibration with a precision of $\pm 0.01{ }^{\circ} \mathrm{C}$ using a thermometer calibrated against a NISTcertified thermometer. This temperature is reported in the data tables as "TEMP_PCO2" and showed no variation at a limit of $\pm 0.01^{\circ} \mathrm{C}$. 


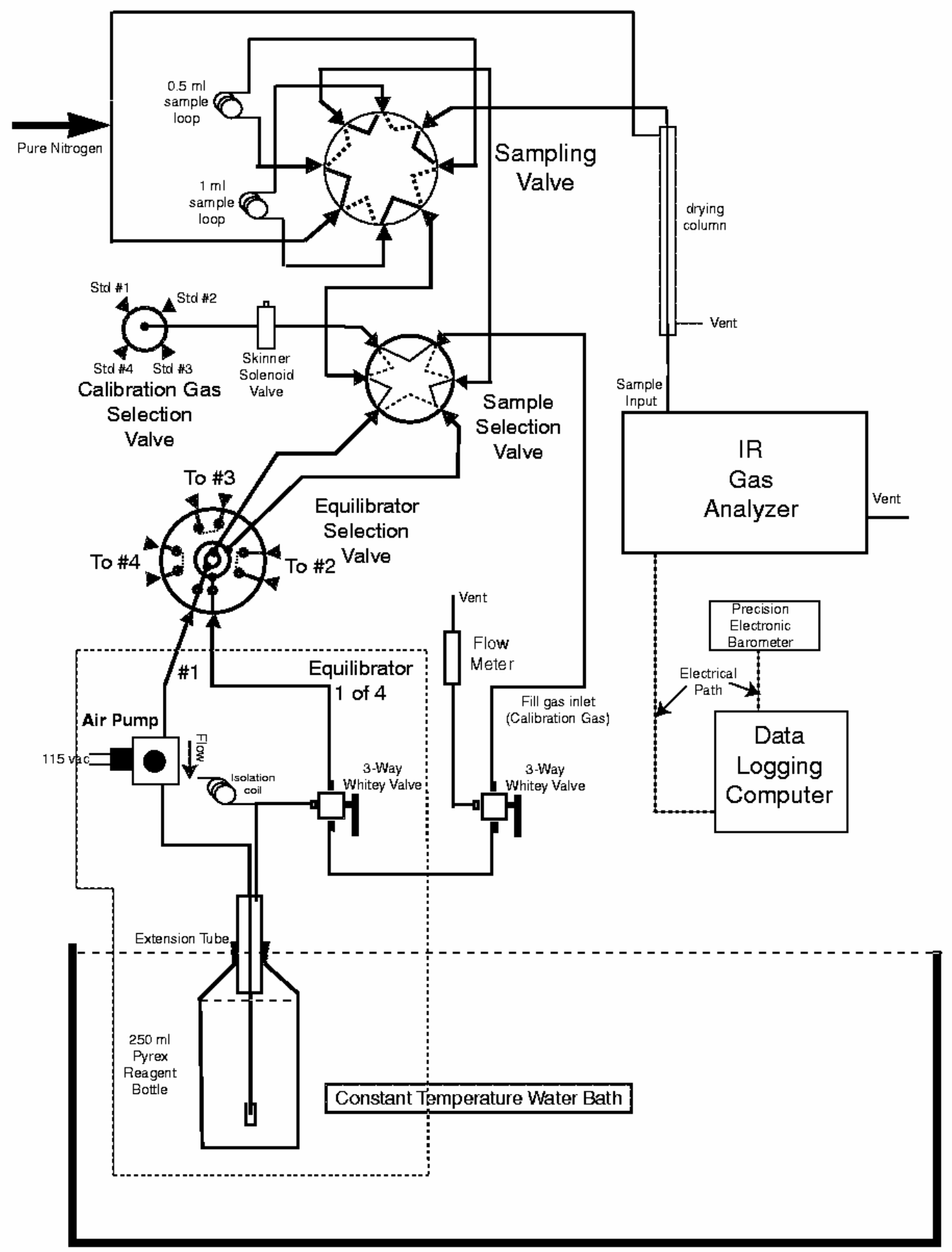

Fig. 4. Schematic diagram for one of the four equilibrator-IR systems used for the pCO2 determination in discrete seawater samples. 
The equilibrated air samples were saturated with water vapor at the temperature of equilibration and had the same $\mathrm{pCO}_{2}$ as the water. By injecting the air aliquot into the IR analyzer after the water vapor was removed, the concentration of $\mathrm{CO}_{2}$ was measured. Therefore, the effect of water vapor must be taken into consideration for computing $\mathrm{pCO}_{2}$ as follows:

$$
p \mathrm{CO}_{2}(\mu \mathrm{atm})=\left[C_{\text {meas }}(\mathrm{ppm})\right] \times[\text { total press. of equilibration }(\mathrm{atm})-\mathrm{water} \text { vapor press. }(\mathrm{atm})]
$$

where $C_{\text {meas }}$ is the mole fraction concentration of $\mathrm{CO}_{2}$ in dried equilibrated air. The total pressure of equilibrated air is measured by having the headspace in the equilibrator flask always at atmospheric pressure. The latter was measured with an electronic barometer at the time each equilibrated air sample was injected into the IR analyzer for $\mathrm{CO}_{2}$ determination. The water vapor pressure was computed at the equilibration temperature, and salinity of the seawater. $C_{\text {meas }}$ was determined by using a quadratic equation fit to three of the calibration gas mixtures.

The concentrations for standard gases used are traceable to the WMO reference scale through analysis in the laboratories of C. D. Keeling of SIO (La Jolla, California) and of Pieter P. Tans of NOAA/CMDL (Boulder, Colorado). The values of the standard gas mixtures used during this cruise were $366.52 \mathrm{ppm}$ $\mathrm{CO}_{2}, 788.0$ ppm $\mathrm{CO}_{2}$, and 1211.4 ppm $\mathrm{CO}_{2}$.

Corrections were made to account for the change in $\mathrm{pCO}_{2}$ of the sample water due to the transfer of $\mathrm{CO}_{2}$ between the water and circulating air during equilibration. We know the $\mathrm{pCO}_{2}$ in equilibrated, perturbed water and the $\mathrm{TCO}_{2}$ by coulometry before the equilibration. We can also calculate the change in $\mathrm{TCO}_{2}$ in the water based on the change in $\mathrm{pCO}_{2}$ between the post-equilibrium value and the known concentration in the pre-equilibrium condition. With the pre-equilibrium $\mathrm{TCO}_{2}$ plus the perturbation in $\mathrm{TCO}_{2}$ during equilibration, the post-equilibrium $\mathrm{TCO}_{2}$ value was obtained. Using the post-equilibrium $\mathrm{TCO}_{2}$ and measured $\mathrm{pCO}_{2}$ values, TALK at the end of the equilibration was calculated, using the temperature, salinity, phosphate, and silicate data. Since the perturbation does NOT change the TALK, the pre-equilibrium $\mathrm{pCO}_{2}$ from the pre-equilibrium $\mathrm{TCO}_{2}$, the calculated TALK, and the temperature, salinity, etc., were calculated. This is the value that was reported as $\mathrm{pCO}_{2}$, the pre-equilibrium calculated value. The magnitude of this correction is generally less than $2 \mu$ atm. Details of the computational scheme are presented in a DOE technical report by Takahashi, et al. (1998).

The $\mathrm{pCO}_{2}$ values reported in this data set are expressed as micro-atmospheres at the temperature of equilibration. The precision of the $\mathrm{pCO}_{2}$ measurement for a single hydrographic station was estimated to be about $\pm 0.15 \%$ based on the reproducibility of replicate equilibrations. The station-to-station reproducibility was estimated to be about $\pm 0.5 \%$. 


\section{DATA CHECKS AND PROCESSING PERFORMED BY CDIAC}

An important part of the numeric data packaging process at CDIAC involves the QA of data before distribution. Data received at CDIAC are rarely in a condition that would permit immediate distribution, regardless of the source. To guarantee data of the highest possible quality, CDIAC conducts extensive QA reviews that involve examining the data for completeness, reasonableness, and accuracy. The QA process is a critical component in the value-added concept of supplying accurate, usable data for researchers.

The following information summarizes the data processing and QA checks performed by CDIAC on the data obtained during the R/V Knorr cruise along WOCE Sections AR24, A24, A20, and A22 in the North Atlantic Ocean.

1. The final carbon-related data were provided to CDIAC by the ocean carbon measurement principal investigators listed in Section 2. The final hydrographic and chemical measurements and the station information files were provided by the WHPO after quality evaluation. A FORTRAN 90 retrieval code was written and used to merge and reformat all data files.

2. Every measured parameter for each station was plotted vs depth (pressure) to identify questionable data points using the Ocean Data View (ODV) software (Schlitzer 2001) Station Mode (Fig. 5).

3. Section plots for every parameter were generated using ODV's Section Mode in order to map a general distribution of each property along all North Atlantic Ocean sections (Fig. 6).

4. To identify "noisy" data and possible systematic, methodological errors, property-property plots were generated (Fig. 7) for all parameters, carefully examined, and compared with plots from previous expeditions in the North Atlantic.

5. All variables were checked for values exceeding physical limits, such as sampling depth values that are greater than the given bottom depths.

6. Dates, times, and coordinates were checked for bogus values (e.g., values of MONTH $<1$ or $>12$; DAY $<1$ or $>31$; YEAR $<1996$ or $>1997$; TIME $<0000$ or $>2400$; LATITUDE $<7.000$ or $>67.000$; LONGITUDE $<-68.000$ or $>-8.000$.

7. Station locations (latitudes and longitudes) and sampling times were examined for consistency with map and cruise information supplied by principal investigators.

8. The designation for missing values, given as -9.0 in the original files, was changed to -999.9 for consistency with other oceanographic data sets. 


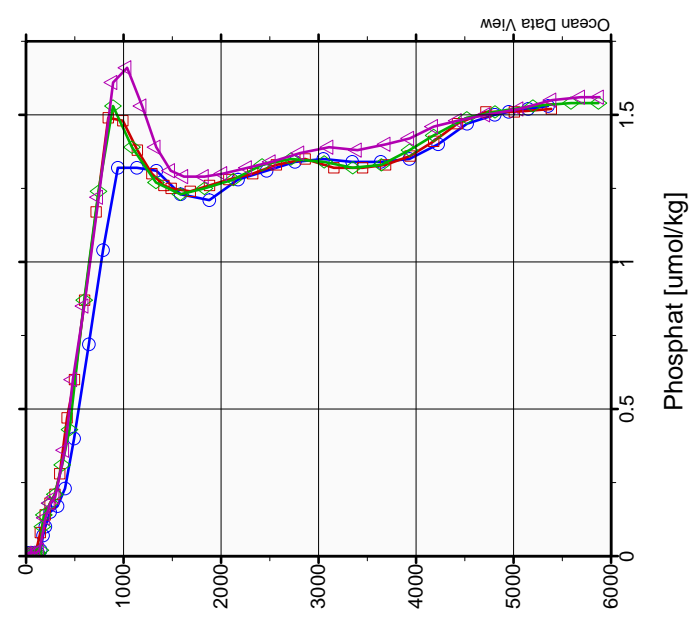

[w] प1də0

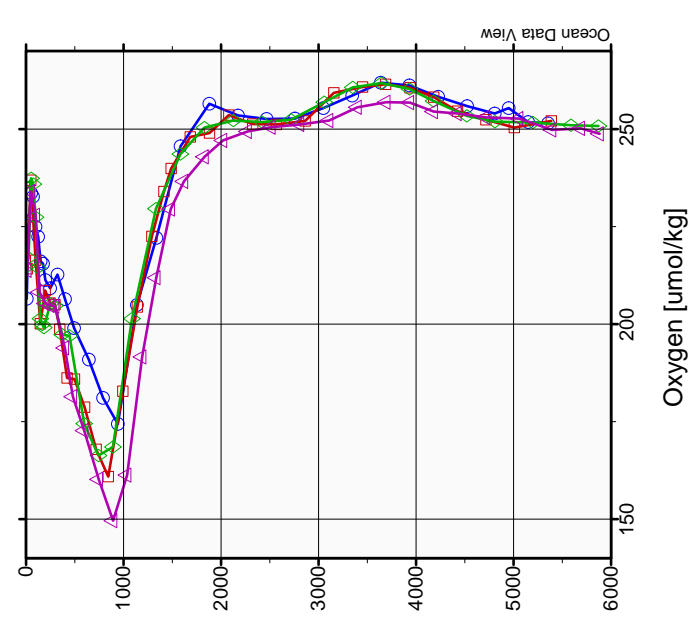

[w] บ1də0

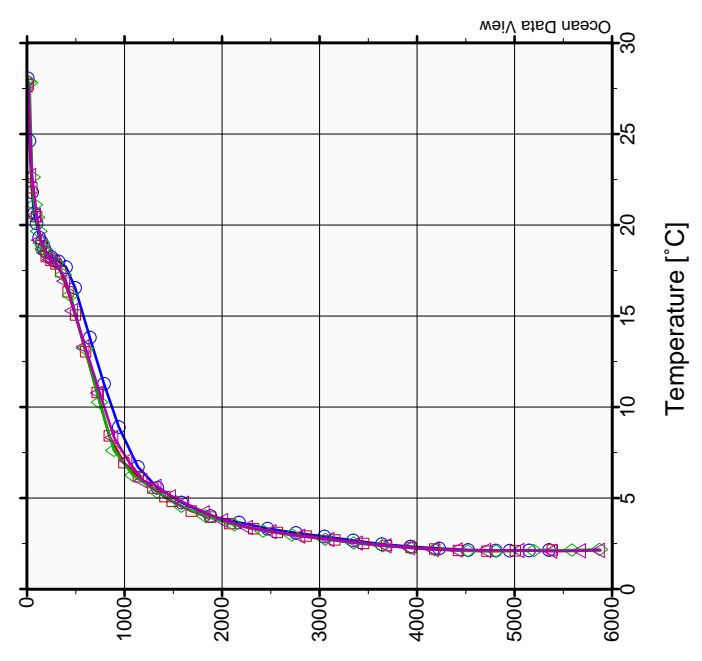

[w] บ1də0
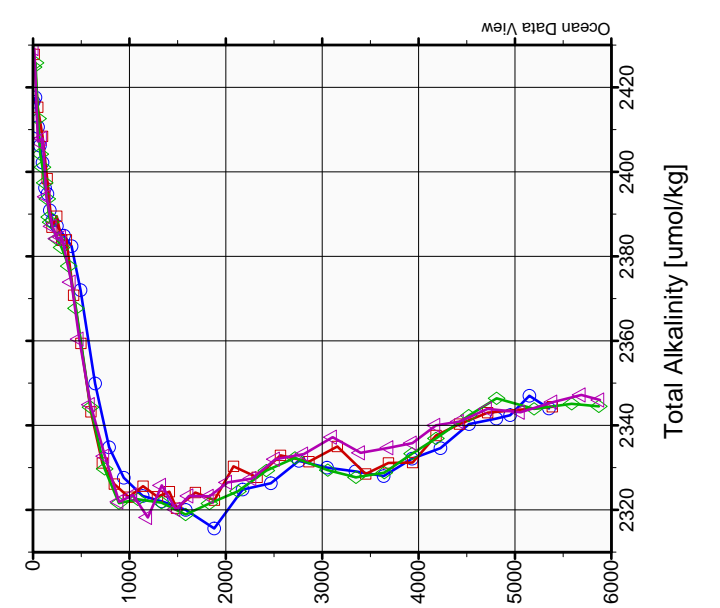

[W] प1də0

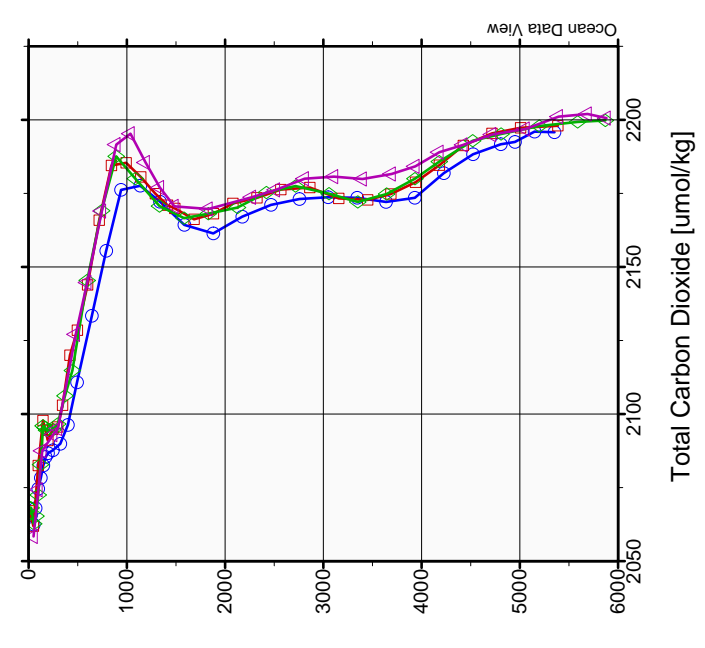

[W] प1də0

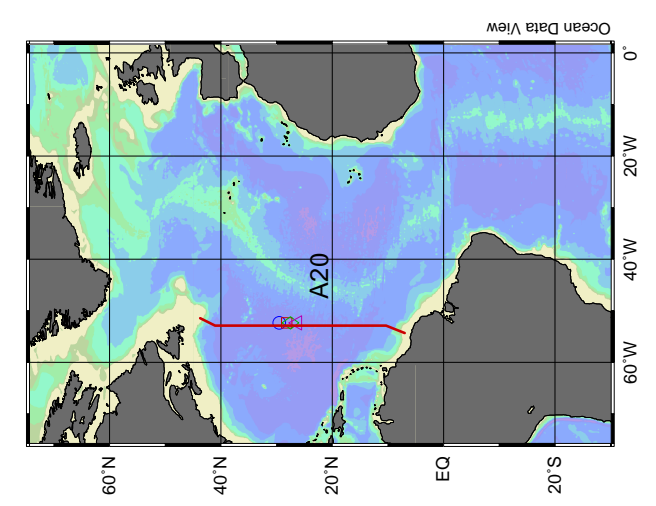

定 


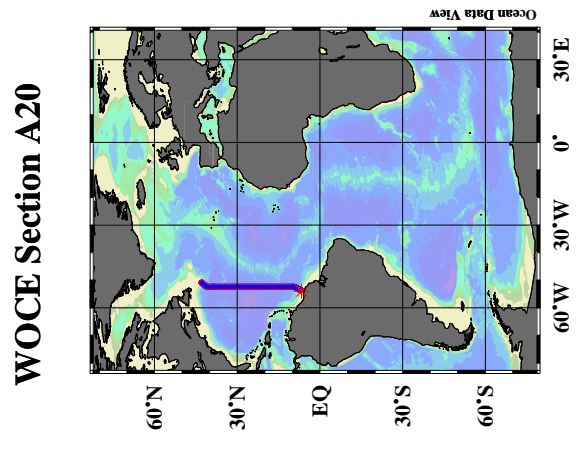

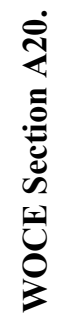

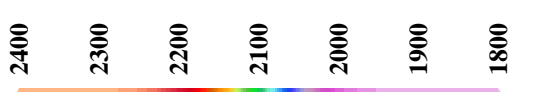

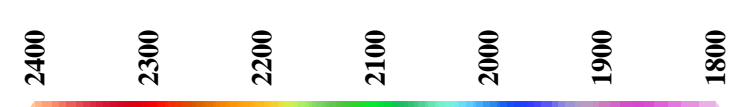
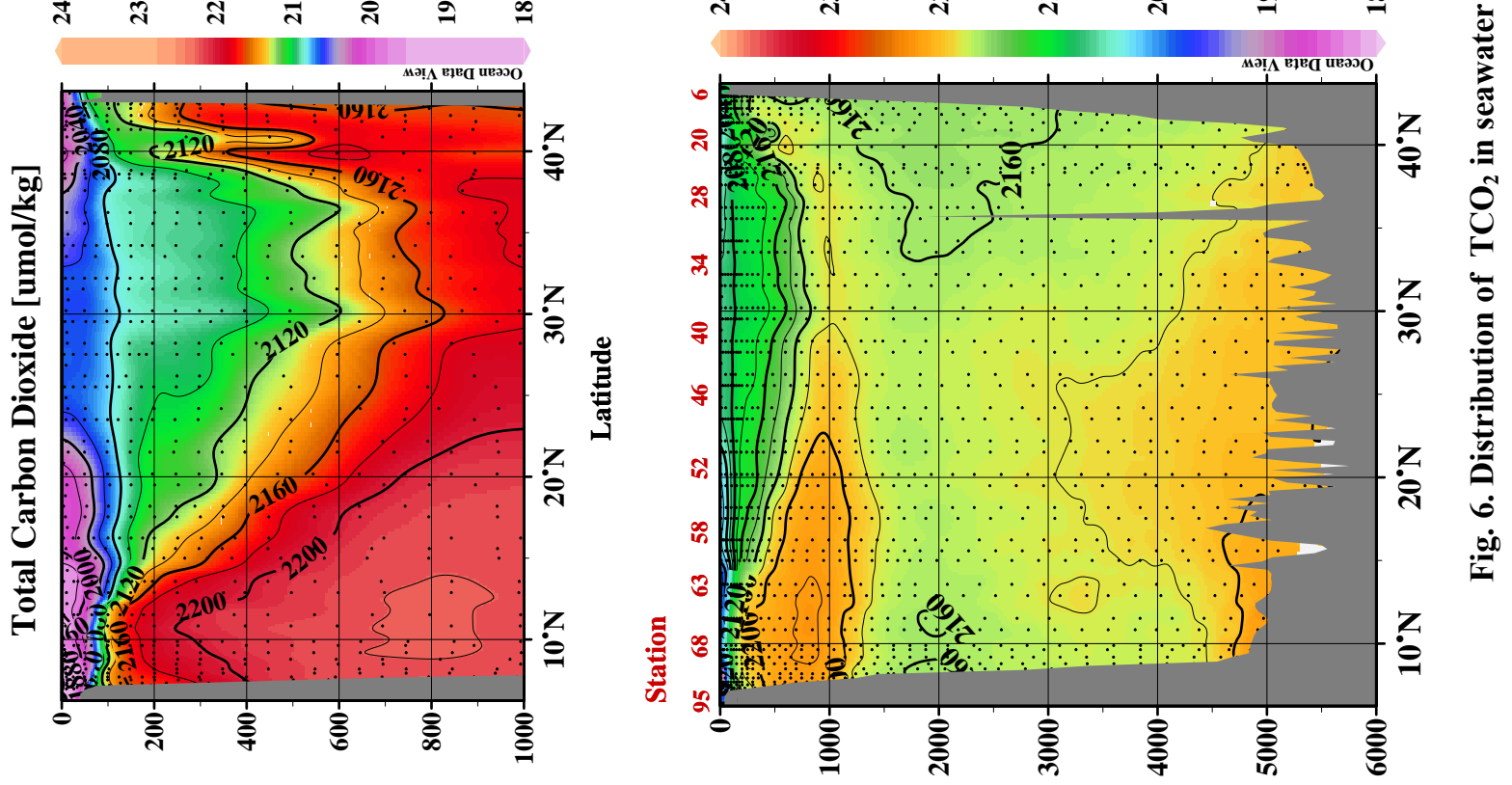

[u] чрdәव

[u] чрdәव 

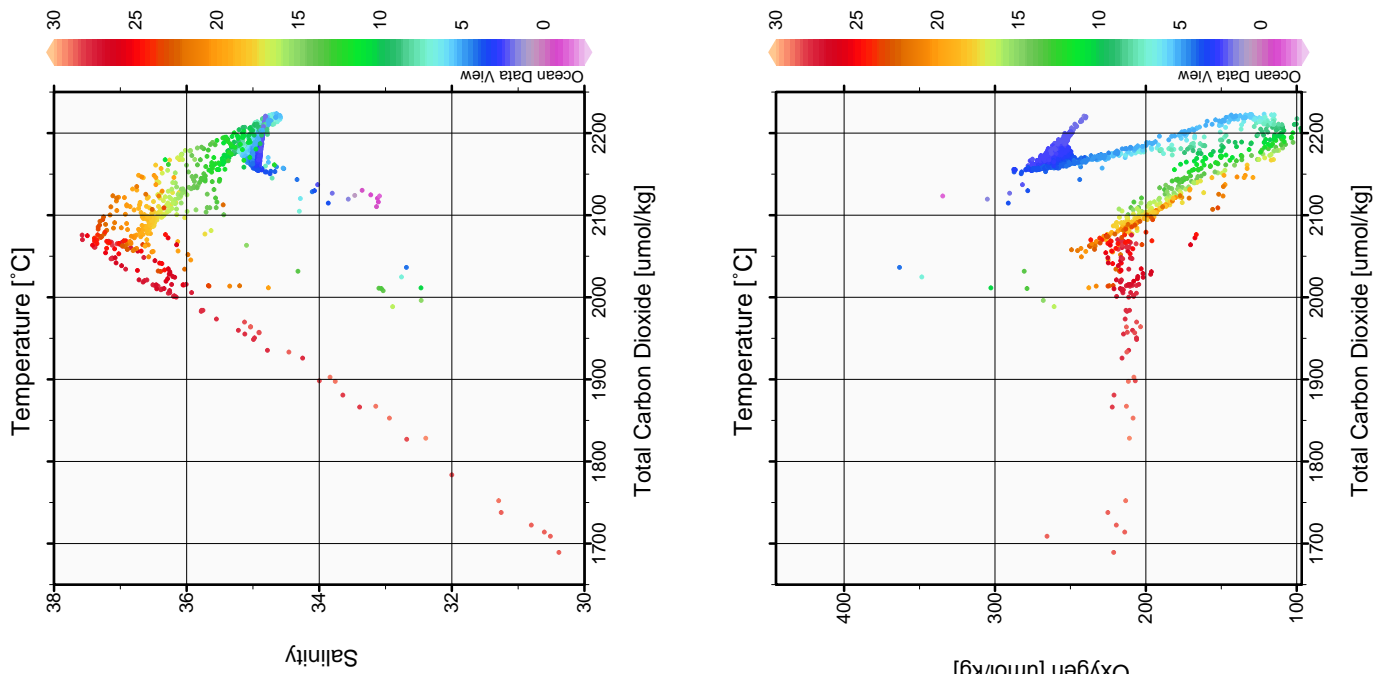

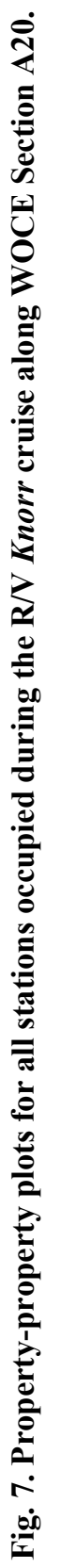
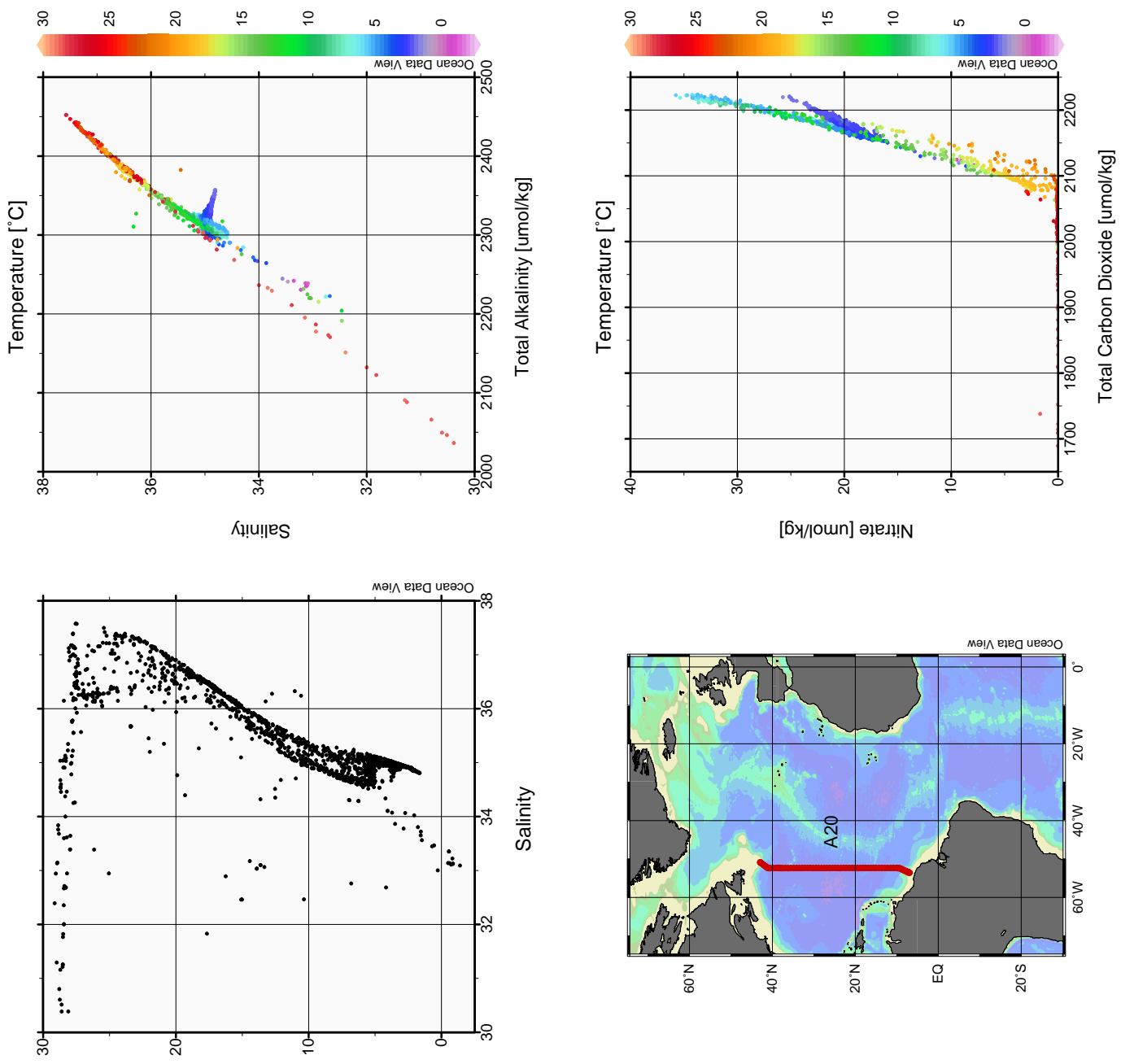

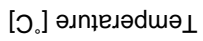




\section{HOW TO OBTAIN THE DATA AND DOCUMENTATION}

This data base (NDP-082) is available free of charge from CDIAC. The complete documentation and data can be obtained from the CDIAC oceanographic Web site (http://cdiac.ornl.gov/oceans/doc.html), through CDIAC's online ordering system (http://cdiac.ornl.gov/pns/how_order.html), or by contacting CDIAC (see below).

The data are also available from CDIAC's anonymous file transfer protocol (FTP) area via the Internet. Please note that, to access these files, your computer must have FTP software loaded on it (this is built into most newer operating systems). Use the following commands to obtain the data base.

ftp cdiac.ornl.gov or $>$ ftp 160.91.18.18

Login: "anonymous" or "ftp"

Password: your e-mail address

ftp $>$ cd pub/ndp082/

$\mathrm{ftp}>\operatorname{dir}$

ftp $>$ mget (files)

$\mathrm{ftp}>$ quit

Contact information:

Carbon Dioxide Information Analysis Center

Oak Ridge National Laboratory

P.O. Box 2008

Oak Ridge, Tennessee 37831-6335

U.S.A.

Telephone: (865) 574-3645

Telefax: (865) 574-2232

E-mail: cdiac@ornl.gov

Internet: http://cdiac.ornl.gov/

\section{REFERENCES}

Armstrong, F. A. J., C. R. Stearns, and J. D. H. Strickland. 1967. The measurement of upwelling and subsequent biological processes by means of the Technicon AutoAnalyzer and associated equipment. Deep-Sea Research 14:381-9.

Atlas, E. L., S. W. Hager, L. I. Gordon, and P. K. Park. 1971. A Practical Manual for Use of the Technicon AutoAnalyzer ${ }^{\circledR}$ in Seawater Nutrient Analyses (revised). Technical Report 215, Reference 71-22, Oregon State University, Department of Oceanography, Oregon.

Bernhardt, H. and A. Wilhelms. 1967. The continuous determination of low-level iron, soluble phosphate and total phosphate with the AutoAnalyzer. Technicon Symposia 1:385-9. 
Bradshaw, A. L. and P. G. Brewer. 1988. High-precision measurements of alkalinity and total carbon dioxide in seawater by potentiometric titration: 1 . Presence of unknown protolyte (s). Marine Chemistry 28:69-86.

Brewer, P. G., C. Goyet, and D. Dyrssen. 1989. Carbon dioxide transport by ocean currents at $25^{\circ} \mathrm{N}$ latitude in the Atlantic Ocean. Science 246:477-79.

Bryden, H. L., and M. M. Hall. 1980. Heat transport by ocean currents across $25^{\circ} \mathrm{N}$ latitude in the North Atlantic Ocean. Science 207:884.

Carpenter, J. H. 1965. The Chesapeake Bay Institute technique for the Winkler dissolved oxygen method. Limnology and Oceanography 10:141-3.

Chipman, D. W., J. Marra, and T. Takahashi. 1993. Primary production at $47^{\circ} \mathrm{N}$ and $20^{\circ} \mathrm{W}$ in the North Atlantic Ocean: A comparison between the ${ }^{14} \mathrm{C}$ incubation method and the mixed layer carbon budget. Deep-Sea Research 40:151-69.

Clayton, T. and R. H. Byrne. 1993. Calibration of m-cresol purple on the total hydrogen ion concentration scale and its application to $\mathrm{CO}_{2}$-system characteristics in seawater. Deep-Sea Research 40:2115-2129.

Culberson, C. H., G. Knapp, M. Stalcup, R. T. Williams, and F. Zemlyak. 1991. A Comparison of Methods for the Determination of Dissolved Oxygen in Seawater. WHP Office Report, WHPO 91-2. WOCE Hydrographic Program Office, Woods Hole, Mass.

DOE (U.S. Department of Energy). 1994. Handbook of Methods for the Analysis of the Various Parameters of the Carbon Dioxide System in Seawater. Version 2.0. ORNL/CDIAC-74.

A. G. Dickson and C. Goyet (eds.). Carbon Dioxide Information Analysis Center, Oak Ridge National Laboratory, Oak Ridge, Tenn.

Gordon, L. I., J. C. Jennings, Jr., A. A. Ross, and J. M. Krest. 1992. A Suggested Protocol for Continuous Flow Automated Analysis of Seawater Nutrients (Phosphate, Nitrate, Nitrite and Silicic Acid) in the WOCE Hydrographic Program and the Joint Global Ocean Fluxes Study. Grp. Tech. Rpt. 92-1. Chemical Oceanography Group, Oregon State University, College of Oceanography, Oregon.

Gordon, L. I., J. C. Jennings, Jr., A. A. Ross, and J. M. Krest. 1994. A Suggested Protocol for Continuous Flow Automated Analysis of Seawater Nutrients (Phosphate, Nitrate, Nitrite and Silicic Acid) in the WOCE Hydrographic Program and the Joint Global Ocean Fluxes Study. In WOCE Operations Manual. WHP Office Report WHPO 91-1. WOCE Report No. 68/91. Revision 1. Woods Hole, Mass.

Hager, S. W., E. L. Atlas, L. I. Gordon, A. W. Mantyla, and P. K. Park. 1972. A comparison at sea of manual and autoanalyzer analyses of phosphate, nitrate, and silicate. Limnology and Oceanography 17:931-7.

Holfort, J., K. M. Johnson, B. Schneider, G. Siedler, and D. W. R. Wallace. 1998. Meridional transport of dissolved inorganic carbon in the South Atlantic Ocean. Global Biogeochemical Cycles 12:479-499.

Huffman, E. W. D., Jr. 1977. Performance of a new automatic carbon dioxide coulometer. Microchemical Journal 22:567-73. 
Johnson, K. M., A. E. King, and J. McN. Sieburth. 1985. Coulometric $\mathrm{TCO}_{2}$ analyses for marine studies: An introduction. Marine Chemistry 16:61-82.

Johnson, K. M., P. J. Williams, and L. Brandstroem, and J. McN. Sieburth. 1987. Coulometric $\mathrm{TCO}_{2}$ analysis for marine studies: Automation and calibration. Marine Chemistry 21:117-33.

Johnson, K. M., and D. W. R. Wallace. 1992. The Single-operator Multiparameter Metabolic Analyzer for Total Carbon Dioxide with Coulometric Detection. DOE Research Summary No. 19. Carbon Dioxide Information Analysis Center, Oak Ridge National Laboratory, Oak Ridge, Tenn.

Johnson, K. M., K. D. Wills, D. B. Butler, W. K. Johnson, and C. S. Wong. 1993. Coulometric total carbon dioxide analysis for marine studies: Maximizing the performance of an automated gas extraction system and coulometric detector. Marine Chemistry 44:167-87.

Johnson, K. M., D. W. R. Wallace, R. J. Wilke, and C. Goyet. 1995. Carbon Dioxide, Hydrographic, and Chemical Data Obtained During the R/V Meteor Cruise 15/3 in the South Atlantic Ocean (WOCE Section A9, February-March 1991). ORNL/CDIAC-82, NDP-051. Carbon Dioxide Information Analysis Center, Oak Ridge National Laboratory, Oak Ridge, Tenn.

Johnson, K. M., B. Schneider, L. Mintrop, and D. W. R. Wallace. 1996. Carbon Dioxide, Hydrographic, and Chemical Data Obtained During the R/V Meteor cruise 18/1 in the North Atlantic Ocean (WOCE Section A1E, September 1991). NDP-056. Carbon Dioxide Information Analysis Center (CDIAC), Oak Ridge National Laboratory, Oak Ridge, Tenn.

Johnson, K. M., B. Schneider, L. Mintrop, and D. W. R. Wallace. 1998a. Carbon Dioxide, Hydrographic, and Chemical Data Obtained During the R/V Meteor Cruise 22/5 in the South Atlantic Ocean (WOCE Section A10, December 1992-January 1993). ORNL/CDIAC-113, NDP-066. Carbon Dioxide Information Analysis Center, Oak Ridge National Laboratory, Oak Ridge, Tenn. 49 pp.

Johnson, K. M., A. G. Dickson, G. Eischeid, C. Goyet, P. R. Guenther, R. M. Key, F. J. Millero, D. Purkerson, C. L. Sabine, R. G. Schotle, D. W. R. Wallace, R. J. Wilke, and C. D. Winn. 1998b. Coulometric total carbon dioxide analysis for marine studies: Assessment of the quality of total inorganic carbon measurements made during the U.S. Indian Ocean $\mathrm{CO}_{2}$ Survey 1994-1996. Marine Chemistry 63:21-37.

Johnson, K. M., M. Haines, R. M. Key, C. Neill, B. Tilbrook, R. Wilke, and D.W.R. Wallace. 2001. Carbon Dioxide, Hydrographic, and Chemical Data Obtained During the R/V Knorr Cruises 138-3, -4, and -5 in the South Pacific Ocean (WOCE Sections P6E, P6C, and P6W, May 2-July 30, 1992). ORNL/CDIAC-132, NDP-077. Carbon Dioxide Information Analysis Center, Oak Ridge National Laboratory, Oak Ridge, Tenn. 53 pp.

Knapp, G. P., M. C. Stalcup, and R. J. Stanley. 1990. Automated Oxygen and Salinity Determination. Woods Hole Oceanographic Institution Technical Report No. WHOI-90-35. Woods Hole Oceanographic Institution, Woods Hole, Mass.

Marinenko, G. and J. K. Taylor. 1968. Electrochemical equivalents of benzoic and oxalic acid. Analytical Chemistry 40:1645-51.

Millard, R. C. and K. Yang. 1993. CTD Calibration and Processing Methods Used at Woods Hole Oceanographic Institution. Woods Hole Oceanographic Institution Technical Report. WHOI 93-44. Woods Hole Oceanographic Institution, Woods Hole, Mass., U.S.A. 
Millero, F. J., and A. Poisson. 1981. International one-atmosphere equation of state for seawater. DeepSea Research 28:625-29.

Millero, F. J., J. Z. Zhang, S. Fiol, S. Sotolongo, R. Roy, K. Lee, and S. Mane. 1993a. The use of buffers to measure the $\mathrm{pH}$ of seawater. Marine Chemistry 44:143-152.

Millero, F. J., J. Z. Zhang, K. Lee, and D. M. Campbell. 1993b. Titration alkalinity of seawater. Marine Chemistry 44:153-156.

Millero, F. J., F. Huang, M. Galanter, J. Goen, C. Sabine, C. Thomas, and R. Rotter. 1999. The Total Alkalinity of North Atlantic Waters. University of Miami Technical Report, No. RSMAS-99-002. University of Miami, Miami, Florida.

Roemmich, D., and C. Wunsch. 1985. Two transatlantic sections: Meridional circulation and heat flux in the subtropical North Atlantic Ocean. Deep-Sea Research 32:619-64.

Schlitzer, R. 2001. Ocean Data View. http://www.awi-bremerhaven.de/GEO/ODV. Online publication. Alfred-Wegener-Institute for Polar and Marine Research. Bremerhaven, Germany.

Strickland, J. D. H. and T. R. Parsons. 1972. The Practical Handbook of Seawater Analysis. Bulletin 167, Fisheries Research Board of Canada, 310 pp.

Takahashi, T., D. W. Chipman, S. Rubin, J. Goddard, and S. C. Sutherland. 1998. Measurements of the Total $\mathrm{CO}_{2}$ Concentration and Partial Pressure of $\mathrm{CO}_{2}$ in Seawater during WOCE Expeditions P-16, $P-17$ and P-19 in the South Pacific Ocean, October, 1992-April, 1993. Final Technical Report of Grant No. DE-FGO2-93ER61539 to U. S. Department of Energy, Lamont-Doherty Earth Observatory, Palisades, N.Y. pp. 124.

Taylor, J. K. and S. W. Smith. 1959. Precise coulometric titration of acids and bases. Journal of Research of the National Bureau of Standards 63A:153-9.

UNESCO (United Nations Educational, Scientific, and Cultural Organization). 1981. Background papers and supporting data on the practical salinity scale, 1978. UNESCO Technical Papers in Marine Science 37:144.

Wallace, D. W. R. 2002. Storage and transport of excess $\mathrm{CO}_{2}$ in the oceans: The JGOFS/WOCE global $\mathrm{CO}_{2}$ survey. In J. Church, G. Siedler, and J. Gould (eds.). Ocean Circulation and Climate, Academic Press, 489-521.

Wilke, R. J., D. W. R. Wallace, and K. M. Johnson. 1993. A water-based, gravimetric method for the determination of gas sample loop volume. Analytical Chemistry 65:2403-2406

Youden, W. J. 1951. Statistical Methods for Chemists. Wiley, New York. 


\section{DATA PACKAGE DESCRIPTIONS}

\subsection{File Content and Format Descriptions}

This section describes the content and format of each of the data files that constitute NDP-082 (see Table 7).

Table 7. Content, size, and format of data files

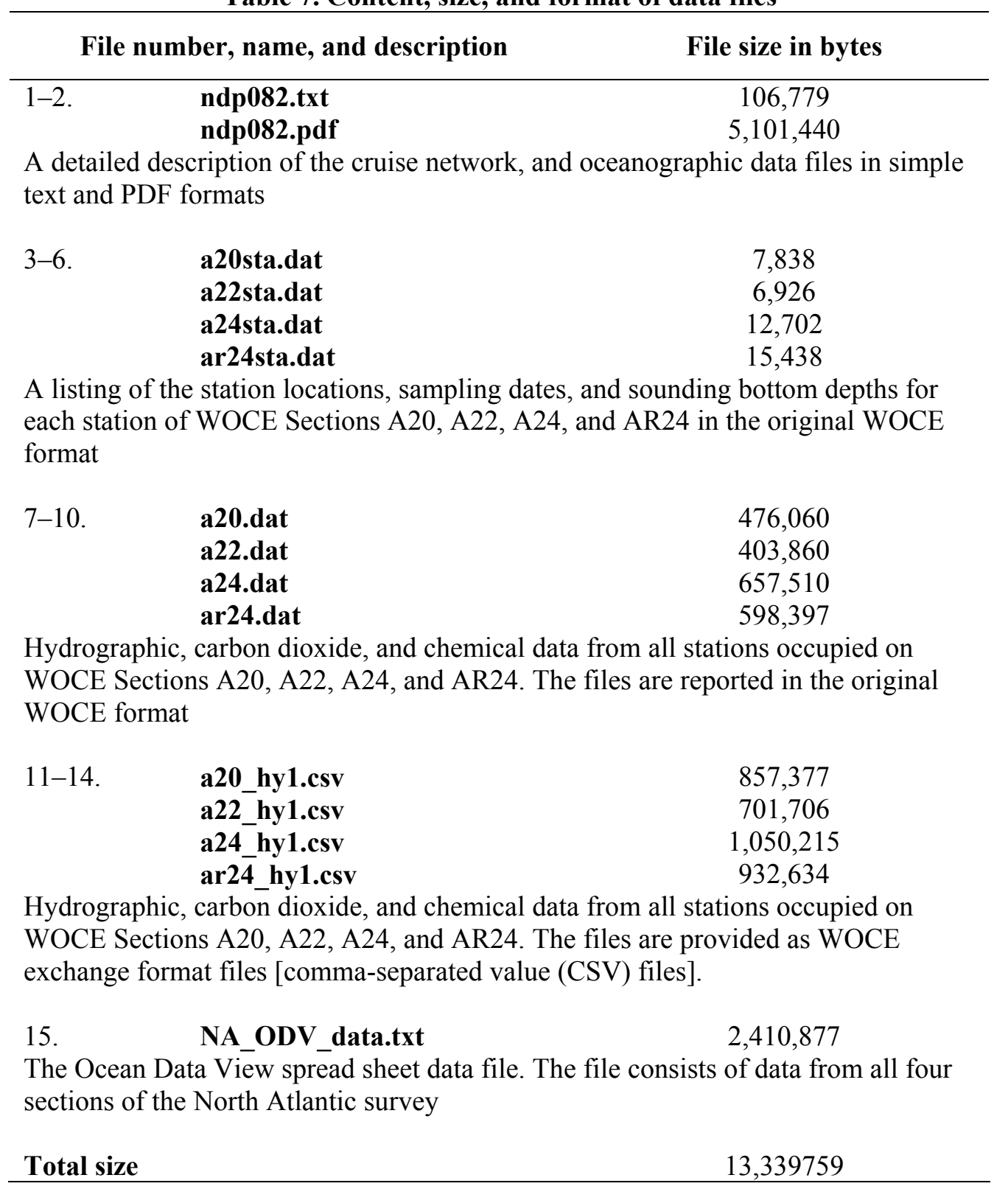




\subsection{Descriptions of Variables}

The station inventory file (*sta.dat) variables are defined as follows:

EXPOCODE Character (A10) expedition code of the cruise

SECT Character (A4) WOCE section number

STNBR Numeric (I3) station number

CAST Numeric (I1) cast number

DATE Character (A10) sampling date (month/day/year)

TIME Character (A4) sampling time [Greenwich mean time (GMT)]

LATITUDE Numeric (F7.3) latitude of the station (in decimal degrees; negative values indicate the Southern Hemisphere)

LONGITUDE Numeric (F8.3) longitude of the station (in decimal degrees; negative values indicate the Western Hemisphere)

DEPTH Numeric (I4) sounding depth of the station (in meters)

The data file $(*$.dat) variables are defined as follows:

STNBR Numeric (I3) station number

CASTNO Numeric (I1) cast number

SAMPNO Numeric (I2) sample number

BTLNBR $^{\text {a }} \quad$ Numeric (I2) bottle number

CTDPRS Numeric (F7.1) CTD pressure (dbar)

CTDTMP Numeric (F7.4) CTD temperature $\left({ }^{\circ} \mathrm{C}\right)$

CTDSAL $^{a} \quad$ Numeric (F7.4) CTD salinity

CTDOXY $\quad$ Numeric (F7.1) CTD oxygen $(\mu \mathrm{mol} / \mathrm{kg})$

THETA Numeric (F7.4) potential temperature $\left({ }^{\circ} \mathrm{C}\right)$

SALNTY $^{a} \quad$ Numeric (F9.4) bottle salinity

OXYGEN $^{a} \quad$ Numeric (F7.1) oxygen concentration $(\mu \mathrm{mol} / \mathrm{kg})$ 


\begin{tabular}{|c|c|c|}
\hline SILCAT $^{a}$ & Numeric (F7.2) & silicate concentration $(\mu \mathrm{mol} / \mathrm{kg})$ \\
\hline NITRAT $^{a}$ & Numeric (F7.2) & nitrate concentration $(\mu \mathrm{mol} / \mathrm{kg})$ \\
\hline NITRIT $^{a}$ & Numeric (F7.2) & nitrite concentration $(\mu \mathrm{mol} / \mathrm{kg})$ \\
\hline PHSPHT $^{a}$ & Numeric (F7.2) & phosphate concentration $(\mu \mathrm{mol} / \mathrm{kg})$ \\
\hline $\mathrm{CFC}-11^{a}$ & Numeric (F8.3) & chlorofluorocarbon 11 (picamole/kg) \\
\hline CFC-12 ${ }^{a}$ & Numeric (F8.3) & chlorofluorocarbon 12 (picamole/kg) \\
\hline TCARBN $^{a}$ & Numeric (F7.1) & total carbon dioxide concentration $(\mu \mathrm{mol} / \mathrm{kg})$ \\
\hline ALKALI $^{a}$ & Numeric (F7.1) & total alkalinity $(\mu \mathrm{mol} / \mathrm{kg})$ \\
\hline $\mathrm{PCO2}^{a}$ & Numeric (F7.1) & partial pressure of $\mathrm{CO}_{2}(\mu \mathrm{atm})$ \\
\hline $\mathbf{P H}^{\mathbf{a}}$ & Numeric (F8.3) & $\mathrm{pH}$ \\
\hline
\end{tabular}

QUALT1 Character (A15) 15-digit character variable that contains data-quality flag codes for parameters underlined with asterisks $\left(^{* * * * * *}\right)$ in the file header

${ }^{a}$ Variables that are underlined with asterisks in the data file's header indicate they have a dataquality flag. Data-quality flags are defined as follows:

$1=$ sample for this measurement was drawn from water bottle but analysis was not received

2 = acceptable measurement

$3=$ questionable measurement

$4=$ bad measurement

$5=$ not reported

$6=$ mean of replicate measurements

$9=$ sample not drawn for this measurement from this bottle 